${ }^{*}$ Graphical Abstract

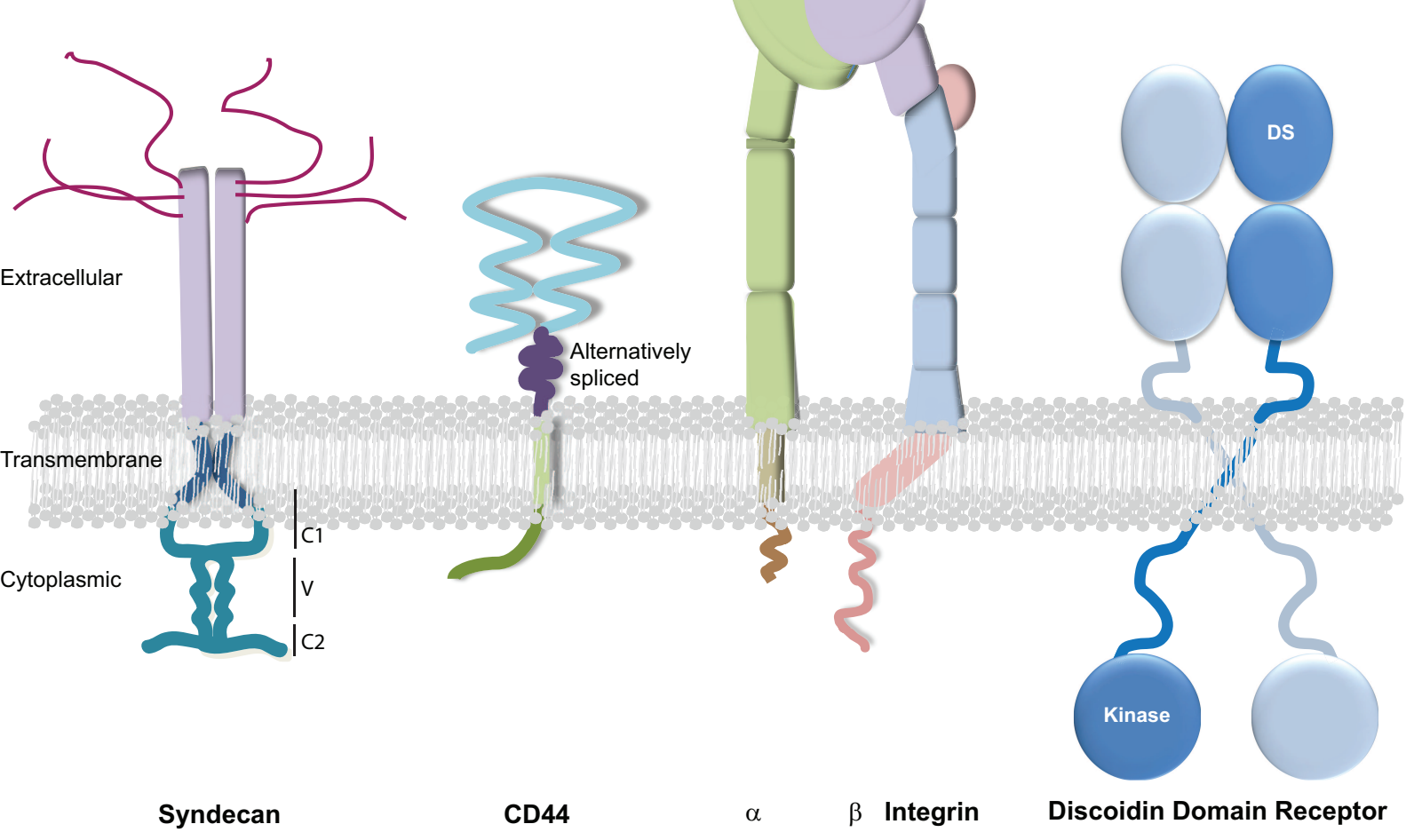




\section{Extracellular Matrix Component Signaling in Cancer}

Hinke A.B. Multhaupt ${ }^{1,2}$, Birgit Leitinger ${ }^{3}$, Donald Gullberg ${ }^{4}$ and John R. Couchman ${ }^{1,2}$

${ }^{1}$ Department of Biomedical Sciences and ${ }^{2}$ Biotech Research \& Innovation Center, University of Copenhagen, Ole Maaløes Vej 5, 2200 Copenhagen N, Denmark

${ }^{3}$ National Heart \& Lung Institute, Imperial College London, Sir Alexander Fleming Building, Exhibition Road, London SW7 2AZ, UK.

${ }^{4}$ Department of Biomedicine and Centre for Cancer Biomarkers, Norwegian Centre of Excellence, University of Bergen, Jonas Lies Vei 91, N-5009 Bergen, Norway

Corresponding Author: John R. Couchman, Ph.D., Department of Biomedical Sciences, University of Copenhagen, Ole Maaløes Vej 5, 2200 Copenhagen N, Denmark john.couchman@bric.ku.dk

+4535325670 (tel)

Keywords: discoidin domain receptors, integrin, proteoglycan, syndecan, adhesion, migration 


\section{Abstract}

Cell responses to the extracellular matrix depend on specific signaling events. These are important from early development, through differentiation and tissue homeostasis, immune surveillance and disease pathogenesis. Signaling not only regulates cell adhesion cytoskeletal organisation and motility, but also provides survival and proliferation cues. The major classes of cell surface receptors for matrix macromolecules are the integrins, discoidin domain receptors and transmembrane proteoglycans such as syndecans and CD44. Cells respond not only to specific ligands, such as collagen, fibronectin or basement membrane glycoproteins, but also in terms of matrix rigidity. This can regulate the release and subsequent biological activity of matrix-bound growth factors, for example transforming growth factor- $\beta$. In the environment of tumours, there may be changes in cell populations and their receptor profiles as well as matrix constitution and protein cross-linking. Here we summarize roles of the three major matrix receptor types, with emphasis on how they function in tumour progression.

\section{Introduction}

Through the discovery of specific receptors for matrix glycoproteins, nearly three decades ago, began a process by which it was increasingly realized that extracellular matrix (ECM) could influence cellular events at a molecular level. Prior to that, it had been thought that the ECM was structurally important but that cells were responding to the physical environment but not the molecular environment. Now it is recognised that both elements are important; interactions between specific collagens and glycoproteins with receptors signal to the cell interior, generating control of the cytoskeleton, survival, differentiation and gene expression. In addition, physical forces, generated by cellular interactions with the ECM in turn can also influence proliferation and migration in normal tissues but are in the spotlight currently with respect to tumor stroma and progression.

In this review, the focus is on three distinct receptor groups, the integrins, a major class of ECM receptor, the discoidin domain receptors (DDRs), receptors for collagens and a varied group of cell surface proteoglycans. Each class of receptor is widespread, and increasingly it is recognized they may contribute essential functions in normal development and homeostasis, but altered in the malignant state. Moreover, these three receptor classes often do not work in isolation, but in combination with each other and with other types of receptor, for example growth factor receptors. These can be part of complexes with integrins and syndecan proteoglycans, with examples being known for receptors for 
epidermal growth factors, fibroblast growth factors, vascular endothelial growth factor and insulin-like growth factors. Other ECM receptors associate with cytokine and chemokine receptors, with implications for inflammation.

\section{Integrins and tumorigenesis}

Integrins are heterodimeric cell surface receptors that mediate interactions with the ECM and play an important role in the tumor microenvironment. Both $\alpha$ and $\beta$ subunits are transmembrane proteins with the $\beta$ subunit, in particular, linking to cytoskeletal and regulatory proteins (Figure 1). Prominent among the signaling molecules associated with integrins are focal adhesion kinase and the protooncogene, Src $[1,2]$. ECM ligands interact at the distal tip of the integrin dimers, and through signaling not only control cell adhesion, migration and actin cytoskeletal architecture, they are also a key component of anchorage-dependent survival mechanisms. Normal cells deprived of integrin-driven adhesion can enter anoikis and undergo cell death [3], a process often bypassed in the transformed cell. A further important property of integrins in many cells, notably leukocytes, is that they may exist in inactive, or low affinity conformations, or in extended, high affinity forms [4]. A key requisite for activation is the binding of talin to the cytoplasmic domain of the $\beta$ subunit $[4,5]$. Talin serves as an adapter molecule for other actin-associated proteins such as vinculin [6]. Low affinity conformers can be activated by a process of "inside-out" signaling deriving from other receptor signal cascades, e.g. growth factors [4].

Integrins are present on the surfaces of nearly all nucleated cells, and therefore are present on tumour cells, and in solid tumours, as well as in cells of the stroma. There have been several detailed recent reviews of integrin roles in tumour progression [7-11]. However, a major and important cell type within the stroma is the "cancer-associated fibroblast" (CAF) [12-14], which has received less attention and is the focus here. This term in fact describes a group of fibroblastic cells of different origin, some of which share characteristics with myofibroblasts in granulation tissue during wound healing and tissue fibrosis [15]. CAFs are the major producers of ECM in the tumour, but they are also involved in the dynamic re-organization and remodeling of the ECM, which affects proliferation, survival and migration of the tumour cells. The ECM also serves as a reservoir of growth factors and cytokines that take part in bidirectional communication that occurs between the stroma and the tumour cells $[16,17]$. In addition, crosslinking and other factors affecting the stiffness of the ECM have been shown to affect tumour progression and invasion $[18,19]$. Recent data also suggest the CAF-ECM interactions are involved in regulating the metastatic niche as well as chemoresistence [20]. 


\subsection{Integrin expression on CAFs}

In vitro culture of fibroblasts changes the integrin repertoire. Integrins identified under in vitro conditions are, therefore, not necessarily the same as those of CAFs in vivo. Accumulated data from different types of fibroblasts have shown that integrins include the collagen-binding integrins $\alpha 1 \beta 1$, $\alpha 2 \beta 1$ and $\alpha 11 \beta 1$, the RGD -binding integrins $\alpha 4 \beta 1, \alpha 4 \beta 7$ (on lung fibroblasts), $\alpha 5 \beta 1, \alpha 9 \beta 1, \alpha v \beta 1, \alpha v \beta 3$, $\alpha \vee \beta 5$ and $\alpha \vee \beta 8$, and the laminin-binding integrin $\alpha 3 \beta 1$. Recent data from fibrosis models suggest that in some types of fibrosis a substantial fraction of the myofibroblasts are derived from perivascular pericytes $[21,22]$. Therefore in the context of fibrosis or CAFs, the mesenchymally derived cell population called myofibroblasts constitutes a more heterogeneous cell mixture compared to resident tissue fibroblasts in a tissue. Furthermore, the balance between cells of different origins change during tissue regeneration/fibrosis. In some organs the main part of the fibrotic stroma is derived from a small pool of resident perivascular Gli1 expressing mesenchymal stem cells which during fibrotic reaction expands to become the major producers of ECM [23]. It is likely that similar dynamics exist for different CAF populations in the stroma.

More work has been performed on myofibroblast integrins in relation to wound healing and fibrotic conditions than CAF integrins. In the fibrosis field integrin $\alpha v \beta 1$ has recently received considerable attention following the findings that it is able to bind latency associated peptide (LAP) and thereby activate TGF- $\beta$ [22], while blocking of $\alpha v \beta 1$ function with a small molecule inhibitor was found to attenuate experimental liver and lung fibrosis [22]. In table 1 some available data on integrin expression in myofibroblasts and CAFs is presented.

\subsubsection{Collagen-binding integrins}

The $\alpha 1$ and $\alpha 2$ integrin chains have been described on dermal myofibroblasts, but data on their expression in CAFs are limited [34, 35]. In one histochemical study of colon adenocarcinomas $\alpha$ smooth muscle actin ( $\alpha$-SMA) positive, $\beta$-PDGFR negative stromal cells, expressed high levels of $\alpha 1 \beta 1$ and $\alpha 5 \beta 1$ and some $\alpha 2 \beta 1$ [35]. In general, $\alpha 1$ and $\alpha 2$ integrin chains are widely expressed and can also be expressed in tumour cells as well as vascular and immune cells [36-38]. These integrins are therefore not particularly useful as biomarkers for the tumour CAFs. $\alpha 10$ integrin is normally restricted to cartilage and a very restricted subset of fibroblasts [39]. Curiously, melanoma cells have been reported to express $\alpha 10$, but to our knowledge no expression in CAFs has been reported [40]. $\alpha 11 \beta 1$ integrin is expressed by different fibroblast types and is induced during myofibroblast differentiation [41-46]. Data from wound healing studies in mice demonstrate that $\alpha 11$ affects myofibroblast differentiation in the wound bed [41]. In collagen gels $\alpha 11$-mediated functions synergizing with TGF- $\beta$ 
were demonstrated to be dependent on JNK-signaling [41]. Recent data from mouse models of lung cancer show that $\alpha 11$ expression associated with increased stiffness of the tumours, suggesting that $\alpha 11 \beta 1$-mediated ECM reorganization occurred [42]. In addition to the direct effect of $\alpha 11 \beta 1$ taking part in collagen reorganization, a correlation with lysyl oxidase-like 1(LOXL1) expression was noted. This indirect mode of regulating collagen cross-linking enzyme levels needs further studies to directly link it to $\alpha 11 \beta 1$-mediated molecular mechanisms. Non-small cell lung cancers may express $\alpha 11$ in activated stroma, where it has the potential to be a biomarker for activated CAFs [47]. It will be important to determine if this $\alpha 11$ expression applies to CAFs in other tumours, or whether this is lung-specific. Recently the original xenograft experiments of lung cancer cells co-implanted with fibroblasts, with or without $\alpha 11$, has been validated in immunocompromised SCID mice deficient in $\alpha 11$ [42]. These experiments demonstrated an important role for $\alpha 11$ in the endogenous tumour stroma for tumour growth and metastasis [42]. Since $\alpha 11 \beta 1$ is restricted to the mesenchymallyderived fibroblasts it may be that $\alpha 11$ is part of the gene signature in the leading, invading " trailblazer" cells of metastasizing breast cancer cells [48]. siRNA knockdown of $\alpha 11$ in this experimental system reduced tumour cell invasion.

Interestingly, fibroblast-specific deletion of the $\beta 1$ integrin gene in mice, which leads to a loss of all collagen-binding integrin receptors (but also the 7 additional $\beta 1$-containing integrin heterodimers), was found to interfere with myofibroblast differentiation during skin wound healing [49]. This was described to be due to a decreased activation of latent TGF- $\beta$. The exact mechanism behind this defect was not elucidated, but it would be interesting to examine these data in light of recent results obtained with integrin $\alpha 11-/-$ mice [41] and $\alpha v \beta 1$-blocking reagents [22].

\subsubsection{EDA+ fibronectin-binding integrins}

The alternatively spliced, extra domain A containing (EDA+) fibronectin is a biomarker of activated fibroblasts in wound healing, fibrosis and tumour stroma $[14,15]$. This fibronectin splice form is also expressed in neovasculature in regenerating tissues [50]. Several receptors have been suggested to bind EDA+ fibronectin in fibroblasts including $\alpha 4 \beta 1$ and $\alpha 9 \beta 1$ which bind at a cryptic site that is exposed only after proteolytic cleavage [51]. Separate from the binding of unknown CAF receptors to the EDA domain, the main fibronectin receptor on CAFs, $\alpha 5 \beta 1$, interacts with the RGD motif in the $10^{\text {th }}$ fibronectin type III domain, and early work suggested that presence of EDA domain increased the affinity of $\alpha 5 \beta 1$ interaction [52]. In a classical paper, EDA+ fibronectin was shown to be required for TGF- $\beta$ stimulated myofibroblast differentiation [53]. However, despite EDA+ fibronectin serving as a reliable biomarker for myofibroblasts, careful analysis of tumour stroma in a Rip-tag2 mice model of breast cancer did not support a role for EDA+ fibronectin in CAF activation or $\alpha$-SMA expression [50]. 
This is unlike the situation in lung and cardiac fibrosis where EDA+ fibronectin appears to regulate myofibroblast differentiation. In lung, a candidate for this effect is $\alpha 4 \beta 7$ integrin [27, whereas in the heart the receptor mediating this effect has not been characterized [54], although some data suggest that it might be an indirect mechanism dependent on recruitment of non-integrin toll like receptor-2(TLR-2) expressing macrophages. The recent finding that the toll like receptor 4 (TLR-4) on inflammatory cells binds to EDA+ fibronectin in the skin has suggested this receptor to be a at the core of a co-ordinating mechanism for inflammatory and fibrotic responses in keloids [55].

\subsubsection{TGF- $\beta$ activating integrins}

The $\alpha v$-containing integrins $\alpha v \beta 1, \alpha \vee \beta 3, \alpha v \beta 5$ and $\alpha v \beta 8$ in a variety of fibroblasts and pericytes are reported to activate latent TGF- $\beta$ by binding to the RGD motif of the latency-associated protein (LAP) that is bound to TGF- $\beta$ and the latent TGF- $\beta$ binding protein (LTBP) forming the large latent complex (LLC) $[22,56]$. LTBP anchors the LLC firmly to the stretch-resistant ECM. Cell contraction then "cracks" the ECM bound TGF $\beta$-LAP complex mechanically, releasing active TGF- $\beta$ in a protease independent manner [57]. $\alpha v \beta 8$ on lung fibroblasts has been suggested to take part in lung fibrosis, via a mechanism involving TGF- $\beta$ activation by myofibroblasts [58]. Hinz has recently elegantly demonstrated that stiffness of the ECM can sensitize TGF- $\beta$ to activation [59]. The importance of $\beta 1$ integrin function for TGF- $\beta$ signaling was also underlined by the phenotype of mice lacking the $\beta 1$ integrin associated protein integrin-linked kinase (ILK) in fibroblasts [60]. In these mice, myofibroblast differentiation was severely impaired, corresponding to defective TGF- $\beta$ signaling.

Interesting candidates for mediating these effects in dermal fibroblasts are $\alpha \vee \beta 1$ and $\alpha 11 \beta 1$. Elegant studies in mice trying to resolve the role of TGF- $\beta$ activating integrins in fibrosis have demonstrated the fundamental role of $\alpha v$ integrins on pericyte derived myofibroblasts in liver and fibroblasts/pericytes in the lung [56], and more detailed studies have demonstrated the av $\beta 1$ integrin heterodimer to mediate the integrin dependent activation of TGF- $\beta$ resulting in fibrosis in the lung and liver [22]. The reason for believing that $\alpha 11 \beta 1$ integrin might be important stems from a recent study demonstrating a role for this integrin in myofibroblast differentiation from dermal fibroblasts [41]. However, in contrast to the situation in wound healing and fibrosis, limited information is available on the role of TGF- $\beta$ activating integrins in CAFs. It will be interesting to determine the role of integrin $\alpha \vee \beta 1$ and $\alpha 11 \beta 1$ on CAFs in different tumour types. Whether $\alpha v \beta 1$-dependent and $\alpha 11 \beta 1$-dependent CAF subpopulations contribute to tumour stroma and to the growth of these tumours will be important to assess.

\subsection{Integrin function and CAF differentiation}


Until recently, the prevailing dogma was that once the tumour has reached a certain size and the tumour stroma is well established the major function of the stroma is to nurture and support the growth of the tumour [16]. This dogma has now been challenged [21,61]. Irrespective of the role of the stroma, fibroblasts in the tumour stroma are most often activated; they are differentiated into myofibroblasts characterized by expression of EDA+ fibronectin and $\alpha$-SMA $[14,17]$. For differentiation of a variety of progenitors into myofibroblasts two processes are of major importance: TGF- $\beta$ signaling and cell contraction accompanied by ECM reorganization [62]. Integrins are important for both of these functions. The source of the fibroblasts most likely has bearing on the integrin repertoire of activated fibroblasts. In mouse skin wounds, as much as $30 \%$ of the myofibroblast-like cells in skin wounds are estimated to be contributed by activated NG2 proteoglycan-positive pericytes [63]. Other studies have recently via cell lineage tracing identified papillary dermal- and reticular dermalfibroblasts with distinct biomarker profiles $[64,65]$. It is currently unknown how these fibroblasts populations contribute to the CAF-rich stroma in subcutaneously grown tumours.

\subsection{CAF integrins and tumour cell proliferation}

A number of autocrine and paracrine loops exist in the tumour microenvironment, influencing directly or indirectly tumour growth. These have been reviewed in depth [66-68] elsewhere. Integrin function during these processes in CAFs might be to synergize with growth factor signaling pathways, but also to activate TGF- $\beta$. We have mentioned that the $\alpha 11 \beta 1$ is involved in paracrine signaling [47], but more examples of this modus operandi are likely to exist. In addition to these two central loops maintaining the activated state of CAFs, other paracrine mechanisms affecting the tumour cells or tumour angiogenesis are active. An example of this is the bi-directional PDGF-CC secreted by tumour, which has been shown to recruit PDGF $\alpha$ R-positive fibroblasts and to affect FGF- 2 and FGF-7 synthesis by CAFs, in turn affecting tumour angiogenesis [69].

\subsection{CAF integrins and tumour stiffness}

Several studies suggest that the mechanical stiffness of the matrix is a major determinant of tumour growth $[18,19]$. One role of the CAFs in this context is suggested to be to reorganize the matrix and to facilitate increased crosslinking of the fibrillar collagen matrix. Integrin-dependent MMP activity is likely to be involved as well as integrin-mediated contractile force. The close association between external and internal force in the context of tumour stroma has recently been highlighted in a study of squamous carcinomas [70]. A recent study documented a correlation between integrin $\alpha 11$ expression and LOXL1 activity in the tumour stroma [71]. This is interesting in relation to breast, colon and 
pancreatic cancer models where increased LOX levels and activity was associated with tumour metastasis [72-73].

A second role of matrix stiffness might be to regulate TGF- $\beta$ activation on CAFs. It is very likely that the CAFs have a central role in the TGF- $\beta$ activation in the tumour stroma. Recent elegant studies have shown how a stiff matrix sensitizes the TGF- $\beta$-LAP complex for activation $[59,74]$. However, the role of specific integrin heterodimers in this process remains to be determined.

\subsection{Integrin function in CAF-promoted invasion and metastasis}

Revealing in vitro studies have shown that integrins on contractile CAFs are an integrated part of tunneling of the matrix, paving the way for invading tumour cells [70, 75]. A tissue-, tumour-and stagespecific induction of different MMPs accompanies this process. Some of the molecular details for these processes have been elucidated and shown to include RhoA, Rab21 and YAP [70, 76-78]. In an experimental 3D system in vitro human CAFs from ovarian carcinomas were found to express $\alpha v$ integrins and a limited set of $\beta 1$ integrins [76]. In the same experimental system only the $\alpha 3 \beta 1$ and $\alpha 5 \beta 1$ integrins were found to mediate CAF migration through a complex matrix composed of collagen I and a laminin -111 enriched matrix. In the future it will be important to determine if collective and single cell migration involves similar mechanisms of dissemination and to what degree an active CAF phenotype is needed for the proteolytic activity. Recent data suggest that primary tumour cells bring along CAFs to the new metastatic site [79]. In terms of the soil and seed terminology, the tumour cells bring their soil along. This might serve to condition the new environment for the future expansion of the tumour cells.

In summary, integrins in the CAF context are likely to be key players in matrix synthesis, remodeling, degradation, stiffness regulation, TGF- $\beta$ activation and invasion mediators. Selectively targeting these activities might be a more controllable path to cancer therapy, in concert with other strategies directed to the tumour cells themselves.

\section{Discoidin Domain Receptors}

The discoidin domain receptors (DDRs) are receptor tyrosine kinases (RTKs) that function as collagen receptors $[80,81]$. There are two closely related receptors in this RTK subfamily: DDR1 and DDR2. The DDRs are the only RTKs that interact with structural components of ECMs and are thus key players at the interface between RTKs and matrix receptors. The DDRs are characterised by the presence of a 
name-giving discoidin homology (DS) domain in their extracellular regions followed by a tightly linked domain of similar structure: the discoidin-like (DS-like) domain (Figure 2) [82]. Both DDRs are widely expressed in different tissues, throughout development and in adult organisms [81]. DDR1 is mainly found in epithelial cells while DDR2 expression predominates in connective tissues that originate from embryonic mesoderm. In addition, the DDRs are also present in immune cells.

While the DDRs fulfil important roles in embryo development (DDR1 being essential for murine mammary gland development and DDR2 for bone growth in mice and humans), their functions in adult tissues are less well defined [81]. At the cellular level, the DDRs control fundamental processes, including cell proliferation, differentiation, migration and survival, which are typically regulated by RTKs. In addition, they contribute to ECM remodelling by controlling the expression and activity of matrix metalloproteinases. Dysregulation of DDR function and/or expression contributes to disease progression of a wide variety of human disorders, including organ fibrosis, arthritis and a long list of cancers $[81,83,84]$. Both DDRs are considered valid therapeutic targets, but mechanistic insight into their roles in various diseases is largely at an early stage.

\subsection{DDR Signalling}

Among RTKs, the DDRs have a unique mechanism of activation which is as yet not fully characterised. The DDRs bind to a number of different collagen types, with fibril-forming collagens acting as ligands for both DDR1 and DDR2 $[85,86]$. Other collagens have distinct DDR binding preferences, such as the basement membrane collagen type IV, which binds only to DDR1, not DDR2 [85-87]. The DDR binding mode to fibrillar collagens is known at atomic detail. Both DDRs bind with high affinity to a six amino acid motif, GVMGFO (O is hydroxyproline), within collagens I, II and III [88, 89]. This motif is accommodated in a trench formed by several conserved surface-exposed loops at the 'top' of the DS domain, with all key collagen binding residues conserved between DDR1 and DDR2 [90, 91]. However, how collagen binding to the extracellular DS domains induces intracellular kinase activation is not known. In contrast to most other RTKs, which are thought to be present as monomers in the absence of ligand and to dimerise upon ligand binding [92], the DDRs are constitutive dimers [93-95]. Therefore, the model of ligand-induced receptor dimerisation does not apply to the DDRs. In addition, collagen-induced DDR phosphorylation occurs with protracted kinetics. Typical RTKs respond to ligand binding by autophosphorylation of cytoplasmic tyrosine residues within seconds to minutes, but this process is delayed for the DDRs and occurs in the timeframe of hours [85, 86]. At present, the cellular mechanisms behind the slow phosphorylation reaction are unknown. Collagen-induced DDR 
phosphorylation is also sustained for many hours, but we do not understand the triggers that switch off DDR-induced signalling.

Ligand binding of RTKs induces phosphorylation of distinct tyrosine residues that serve as docking sites for the recruitment of signalling proteins [92]. For the DDRs, only a handful of direct signalling partners have been identified, including the adaptors ShcA for both DDR1 and DDR2 $[85,96]$ and Nck2 for DDR1 [97]. Other molecules known to interact with phosphorylated DDR1 include the phosphatases SHP-1 $[98]$ and SHP-2 $[97,99]$ and members of the Stat family of transcription activators [99, 100]. For DDR2, downstream effectors include SHP-2, Nck1, the Src family kinase Lyn and phospholipase C-like 2 [101], but it is not known whether any of these interact directly with the activated receptor.

The DDRs initiate different signalling pathways depending on the cell type and context. For example, DDR-activated MAP kinase signalling can occur via distinct MAP kinase family members. In smooth muscle, mammary epithelial and megakaryocytes, DDR1 activates ERK1/2 [98, 102, 103], while in mesangial cells ERK1/2 is repressed by DDR1 [104]. DDR1 can also activate JNK in adipose stromal cells [105]. DDR2 signals to ERK1/2 and p38, but not JNK, in chondrocytes [106] but uses p38 and JNK, and not ERK1/2, in transfected embryonic kidney cells [107]. In osteoblasts, DDR2 signalling activates the transcription factor Runx 2, but conflicting data exist whether this is via p38 MAP kinase or ERK1/2 $[108,109]$.

\subsection{DDRs and Cancer}

Many cancers are characterised by aberrant expression or activities of one or more RTKs, whose dysregulated function can directly contribute to disease progression. It is therefore not surprising that altered DDR expression is found in cancer. Aberrant DDR signalling is thought to contribute to malignancy of a wide range of cancers, including solid tumours as well as blood cancers. The list ranges from breast, lung, brain, ovarian, prostate, head and neck, liver and pancreatic cancer, to lymphomas and leukaemias [83]. A number of studies have shown that dysregulated DDR expression correlates with unfavourable outcomes for patients, and there are active drug development programmes that target the DDRs in various cancers. The roles that the DDRs play in malignancy are likely to be multifaceted, as several distinct functions have emerged. For instance, DDR1 can control cell invasion, collective cell migration, metastasis, resistance to chemotherapy and mediate pro-survival signals [83, 110-113]. Furthermore, it may be involved in the recurrence of certain types of cancer [114]. DDR2 is likewise important in mediating metastasis [115] and may be an oncogenic driver in lung cancer [116]. How the DDRs regulate various steps of cancer progression is not well understood, but it is believed to 
be at least partly through their ability to regulate the interactions of cancer cells with collagen. Therefore, the normal cellular functions of the DDRs that regulate cell proliferation, tissue morphogenesis and cell differentiation may be hijacked by tumour cells, resulting in pro-migratory and pro-invasive phenotypes. This is in keeping with DDR overexpression in highly aggressive cancers, such as gliomas [117] or invasive breast carcinomas (see below).

While other RTKs often contribute to cancer progression through oncogenic receptor mutations that result in altered receptor function, the evidence for somatic $D D R$ mutations acting as oncogenic driver mutations is less clear. For example, several DDR1 mutations were observed in non-small cell lung carcinoma (NSCLC) in one study [118] but these findings were not replicated in another study that specifically sought to identify somatic DDR mutations in NSCLC [119]. Somatic DDR mutations were also found in primary lung adenocarcinoma [120] but the functional significance of these mutations is not clear. A comprehensive study that analysed the entire kinome in squamous cell carcinoma (SCC) of the lung identified somatic DDR2 mutations in about $4 \%$ of tumour samples and cell lines [116]. However, the mutations were not restricted to a particular region in the DDR2 gene and affected both the receptor's globular domains and its juxtamembrane regions. Some of these DDR2 missense mutations seemed to result in an oncogenic gain of function phenotype in vitro, and SCC lines harbouring these mutations were selectively killed by $D D R 2$ knockdown or treatment with dasatinib, a multi-kinase inhibitor [116]. Furthermore, a patient with lung SCC who harboured a DDR2 kinase mutation, but did not have any EGF receptor mutations, responded to a combination of dasatinib and erlotinib (an inhibitor of EGF receptor) treatment, which provided a rationale for clinical use of DDR2 kinase inhibitors [116]. This is backed up by another report on a lung SCC patient who responded to dasatinib treatment and was found to have the same DDR2 kinase mutation [121]. The initial study concluded that gain of functions mutations in DDR2 are oncogenic and provided the first targetable mutations in lung SCC [116] and hence caused much excitement in the field. However, the study did not address the contribution of wild-type DDR2 to oncogenesis, and while several more recent studies have confirmed the occurrence of DDR2 mutations in different patient populations [122-124], it is far from clear whether the mutations are indeed oncogenic and their roles in lung SCC cell signalling are undefined [125]. Notably, in other studies, some of the 'oncogenic' DDR2 mutants either seemed to play tumour suppressive functions [101], or did not contribute to cell proliferation in lung SCC cell lines [126].

\subsubsection{DDR1 and lung cancer}

Notwithstanding the unclear role of $D D R 1$ mutations, there is good evidence that DDR1 plays an important role in tumour progression and metastasis of lung cancer. Overexpression of DDR1 in 
tumour tissue, relative to normal lung tissue, was found in several studies and was associated with poor patient prognosis in all but one report $[111,119,127,128]$. Furthermore, DDR1 mediated cell migration and invasion of NSCLC cell lines in vitro [127, 128], as well as cell survival, homing and colonization in a mouse model for lung cancer metastasis to the bone [111]. DDR1 therefore appears to be a promising molecular target for NSCLC patients with bone metastasis, and it is hoped that its inhibition, together with chemotherapy, may provide clinical benefits. In a phosphoproteomic approach, DDR1 was found to be amongst the most highly phosphorylated RTKs in a set of 150 NSCLC tumour samples [129], and is thus a candidate molecule for an oncogenic driver kinase. However, the relevance of these findings for lung cancer patients needs to be addressed in further studies.

Interestingly, a recent study found lung cancer to be promoted by the minor collagen type IV $\alpha 5$ chain, which has restricted tissue distribution and is highly expressed in lung tissue [130]. In a mouse model, where cancer onset is driven by KRas ${ }^{G 12 D}$, collagen $\alpha 5$ (IV) was indispensable for cancer progression, via its interactions with DDR1, which resulted in downstream ERK activation [130]. Therefore, DDR1mediated carcinoma cell interactions with the matrix can play a key role in lung cancer progression.

\subsubsection{DDRs, Breast Cancer and Epithelial-Mesenchymal Transition}

Collagen plays an important role in breast cancer development and disease progression. Collagendense stroma results in higher tissue density, which is associated with increased breast cancer risk. Dysregulated DDR expression is linked to breast cancer patient survival, although the picture is less straightforward than in lung cancer. In normal breast tissue, DDR1 is expressed in epithelial cells and required for mammary gland function [100, 131]. DDR2 expression, on the other hand, is absent [115]. In invasive breast cancer cell lines, but not in non-invasive cells, DDR1 transcription is negatively regulated by the transcription factor ZEB1 during epithelial-mesenchymal transition (EMT) [132]. Early work on breast carcinoma suggested DDR1 mRNA is abundant in invasive carcinoma and lymph node metastasis [133] but later studies found reduced DDR1 mRNA and protein in various types of breast carcinomas, with somewhat conflicting results as to which type of tumour was affected by altered DDR1 expression $[134,135]$. More recent work has shown that while DDR1 is reduced in tumour tissue, DDR2 expression is upregulated, and that DDR2 expression may define a particularly aggressive subset of breast cancers [136]. Increased DDR2 expression was also linked to poor patient survival in another study [115]. A comprehensive study on DDR expression in invasive breast carcinoma analysed DDR1 and DDR2 expression by immunohistochemistry [137]. While there was no significant association between DDR1 expression level and patient outcome, DDR2 expression correlated with worse survival. In particular, a profile of high DDR2/low DDR1 expression in invasive carcinoma of the triple-negative subtype was associated with poor patient outcome. Therefore, this DDR expression profile may help to identify invasive carcinomas with poor prognosis. 
The molecular mechanism by which DDR2 mediates breast cancer metastasis has been uncovered in a study using invasive breast cancer cell lines [115]. It was found that collagen type I activates DDR2, which in turn mediates ERK2 activation in a Src-dependent manner. This results in phosphorylation of SNAIL1, a transcription factor that mediates EMT. Phosphorylated SNAIL1 accumulates in the nucleus where it is protected from ubiquitination and subsequent proteasomal degradation. Thus, DDR2 stabilises SNAIL1, which was shown to be crucial for breast cancer invasion and migration in vitro, as well as metastasis in vivo. The results of this study, in combination with the reports on increased DDR2 expression being linked to poor patient prognosis $[115,136,137]$, indicate that DDR2 may be a valid drug target for treatment of breast cancer metastasis.

\subsubsection{Prospects for DDR-based Therapy}

Other studies also indicate the DDRs as promising targets for anticancer therapy of metastatic cancer (e.g. DDR2 in metastatic melanoma $[138,139])$. Since dysregulated DDR activity is often associated with particularly aggressive forms of cancers that currently lack targeted treatment options, the development of DDR-selective inhibitors may be a promising therapeutic avenue for rational cancer treatment. A sharp increase in research related to the development of DDR kinase inhibitors reflects this thinking [140-142]. Inhibitors originally developed to target the activity of BCR-ABL kinase are also potent inhibitors of the DDRs $[143,144]$, but these drugs have a very broad specificity and are active against a number of additional kinases. Orally bioavailable small molecule kinase inhibitors with selectivity over other kinases have been developed for DDR1 and DDR2 [126, 145-147]. However, since kinase-independent functions have been discovered for DDR1, in particular its essential role in collective cancer cell migration and invasion [110], DDR-selective kinase inhibitors may not be effective against all DDR-dependent roles in disease progression. Alternative strategies could be based on allosteric sites in the DDR ectodomain, such as function-blocking antibodies that target DDR1 [82]. A further limitation of using single agent DDR selective kinase inhibitors may be related to a general problem of kinase inhibitors in cancer treatment: cancer therapies based on selective kinase targeting often fail eventually when tumour cells become treatment resistant. Recent studies have analysed the mechanisms of drug resistance and found that targeted kinase inhibition can lead to kinome reprogramming. For instance, treatment of breast cancer cells with inhibitors of the non-receptor kinase MEK or the RTK ErbB2 showed rapid reprogramming through induced expression and activation of multiple RTKs (including DDR1) and non-receptor kinases, which mediate growth and survival, thus bypassing the initial inhibition $[148,149]$. Future therapeutic strategies will need to identify effective combination therapies or combining kinase inhibitors with inhibitors that block treatment-induced kinome adaptation [149]. 


\section{Cell Surface Proteoglycans}

Proteoglycans, by definition, consist of a core protein to which one or more glycosaminoglycan chains are covalently attached. There are only a few types of glycosaminoglycans in mammals, these being hyaluronan (HA), chondroitin sulphate (CS) with its close relative dermatan sulphate (DS), heparan sulphate (HS) and keratan sulphate (KS). While HA can reach up to $2 \times 10^{6}$ Daltons, mostly, these polysaccharides consist of around 50-150 repeating disaccharides [150]. Hyaluronan or hyaluronic acid also consists of repeating disaccharides, but in this case is synthesized at, and directly exported from, cell surface synthases [151]. As a result of this unique synthetic pathway, HA is not sulfated or attached to a core protein at synthesis, though it may be cross-linked to proteins in the ECM [152]. HA is recognized as being a particularly important ECM component with respect to tumour biology [153]. The sulphated glycosaminoglycans are among the most complex polysaccharides of bilaterian animals, in large part resulting from the extent and location of sulfate groups along the chain. There have been several recent reviews covering aspects of glycosaminoglycan synthesis, structure and interactions [154-156].

\subsection{The Classes of Cell Surface Proteoglycans}

There are two major classes of cell surface proteoglycan, the glypicans and the syndecans, both with a long evolutionary history. The former are attached to the cell membrane through a phospholipid anchor [157], and are therefore not transmembrane. Moreover, while their heparan sulfate chains (HS) and core proteins interact with, and are important co-receptors for, a number of growth factors and morphogens, they do not appear to have a significant role in cell-ECM interactions, and are not considered further here. Information on these proteoglycans, of which there are six in mammals, can be found elsewhere $[157,158]$. The syndecans are transmembrane proteoglycans, and are present in almost all nucleated cells of mammals. They therefore have the potential to signal and data is now becoming available on how this is achieved. All syndecans bear glycosaminoglycan chains, usually HS, through which interactions with numerous ligands is achieved, including many ECM molecules. It is an important facet of ECM collagens and glycoproteins, that most possess heparin (or HS)-binding motifs, which facilitate interactions with syndecans. These motifs, although generally being cationic, may vary greatly, when comparing say fibronectin, tenascin and interstitial collagens, and have varying affinity. Likely therefore, these motifs have arisen as a result of convergent evolution [159]. 
ECM macromolecules with heparin-binding properties are found in all types of matrices. Glycoproteins such as fibronectin, fibrinogen and von Willebrand Factor are important in wound repair mechanisms and can be derived from the circulation [160]. Others, such as the matricellular proteins including tenascins, thrombospondins and Cyr61/CTGF/NOV (CCN) proteins are also expressed in response to tissue damage or disease, including tumours $[161,162]$. On the other hand, more stable fibrilassociated glycoproteins such as fibrillin-1 has heparin-binding motifs that function in combination with integrin-binding motifs to support cell adhesion [163]. In the case of fibrillin-1 and fibronectin, heparin-binding and integrin-binding motifs are separate yet adjacent $[160,163,164]$ allowing ternary complexes of syndecan, integrin and ECM molecule to form, although integrins themselves are not heparin-binding. This is best characterised with respect to fibronectin, where the crystal structures of the integrin-binding site in repeat $\mathrm{III}_{10}$ and the Hepll domain (repeats $\mathrm{III}_{12-14}$ ) have been solved [165, 166] and the receptor binding and cell adhesion events associated with them have been well characterised [164-168]. These ternary complexes may be involved in cell-ECM junction assembly (e.g. focal adhesions). While many ECM glycoproteins contain heparin (or HS)- binding motifs, so do many collagens, both fibrillary and non-fibrillar, and several enzymes responsible for matrix turnover are also potentially proteoglycan-binding, e.g. MMP2 and 7, ADAM12 and ADAMTS4 [159, 169-172]. However, the functions of syndecan interaction with metalloproteinases are not yet well understood [173].

In addition to the four syndecans of mammals, there are a small number of unrelated transmembrane proteoglycans, some of which interact specifically with ECM components. The NG2/CSPG4 large proteoglycan has a single CS/DS chain, and can interact with type VI collagen, for example [174]. It is a marker of vascular mural cells, and is highly upregulated in melanoma, where it may contribute to invasive behaviour. The mechanisms involve activation of RTKs with sustained ERK1,2 signalling, and integrins [175]. This theme is common to other cell surface proteoglycans, e.g. CD44 and syndecans. In soft tissue sarcoma patients, enhanced CSPG4 expression (with up-regulated collagen VI) allows prognosis and stratification of patients, it being a predictor of metastasis [174].

\subsection{Common Themes in Cell Surface Proteoglycans}

Despite the lack of common core protein structure, there are some principles that unite the transmembrane proteoglycans. First, all connect with the actin cytoskeleton. This involves indirect linkage to actin rather than direct, through intermediates, notably members of the ezrin-radixinmoesin family (ERM). In syndecans, this interaction occurs through a highly conserved juxtamembrane region of the cytoplasmic domain [176]. Similar interactions are noted with CD44 [177]. In the case of syndecan-4, a widespread member of the family and moreover, the only cell surface proteoglycan 
encountered in focal adhesions, there are additional interactions with $\alpha$-actinin [178]. This interaction appears important for linking syndecans to microfilament bundles, and therefore of significance in the control of cell adhesion and migration. However, the actin cytoskeleton has many roles besides cell adhesion, including intracellular trafficking, cytokinesis and endocytosis/exocytosis [179]. Evidence from syndecan-1 suggests that ERM interactions can be important for receptor internalization [180] and clearance, as demonstrated in lipid metabolism [181].

A second common theme with cell surface proteoglycan C-termini is the interaction with PDZ proteins. This has been demonstrated in syndecans, CD44, NG2 and neuropilin 1 [167]and is not restricted to a single PDZ protein, though syntenin features most often. Other partners include synectin (GIPC and CASK [167]. Syntenin was previously known as mda-9 (melanoma differentiation-associated protein 9) with evidence for a supporting role in tumour progression [182]. Recent work also suggests that PDZ interactions have relevance to trafficking, perhaps routing proteoglycans to the cell surface [183]. In addition, however, there is interesting evidence to suggest that syntenin/syndecan in conjunction with the syntenin-binding protein ALIX is involved in, or can enhance, exosome production [184]. There is now much interest in the potential roles of exosome in tumour biology [185] and so a role for syndecan-syntenin in this process deserves further attention.

\subsection{CD44-specific signaling}

Some proteoglycans are sometime substituted with glycosaminoglycans, but at other times not, so they are often referred to as "part-time" proteoglycans. Prominent among these is CD44, a widespread receptor both for growth factors or cytokines as well as HA [186]. It possesses a canonical Ig motif through which interactions with HA take place, a motif that is shared with other ECM proteoglycans that form large aggregates with HA, such as aggrecan of cartilage, brain and other matrices [187]. CD44 has captured a great deal of interest with respect to tumour biology, since expression of some splice variants is strongly associated with tumour progression [188]. The CD44v6 variant can act as a co-receptor with vascular endothelial growth factor receptor or with c-Met, where the hepatocyte growth factor ligand binds both receptors [189]. Downstream signaling is complex in these cases, involving Ras-dependent signalling to survival and apoptosis resistance and to Rac-1 that can promote actin cytoskeletal organisation consistent with migration and invasion [190]. The CD44v6 isoform can also signal to the PI-3K/Akt pathway in response to ECM interactions [191]. In some cells, such as fibroblasts, CD44 is expressed bearing a single CS/DS chain, while the v3 splice variant contains a motif for HS substitution [192] that allows it to serve as a co-receptor for RTKs, e.g. FGFR [159]. Association of CD44 with LRP6 and Frizzled can enhance Wnt signaling with $\beta$-catenin activation and translocation 
to the nucleus where it functions as a transcription factor [186]. There is also much interest in CD44 as a cancer stem cell marker, for example in colon, breast, prostate and pancreatic carcinomas [193].

Signaling responses to HA by CD44 appear to depend on HA size. High molecular weight HA can, in theory, cluster many CD44 receptors on the cell surface. In contrast, in disease or inflammatory states, HA can be cleaved by hyaluronidases or free radicals, generating small oligosaccharides. These in addition to CD44 receptors may also bind to TLR2 and 4 receptors, triggering innate immune responses [194]. CD44, in addition to binding ERM proteins can also indirectly govern the activation of Rho family GTPases, notably Rac1 and RhoA $[189,194]$. This combination of linkage to, and regulation of, the actin cytoskeleton endows CD44 with cell adhesion receptor function, in this case to HA.

\subsection{Syndecan-specific signaling}

The short cytoplasmic domains of syndecans are quite conserved, and we have previously invoked a nomenclature for three small subdomains (Figure 1). The conserved membrane-proximal C1 region interacts with ERM proteins, while the C2 has PDZ-interacting properties. Neither region is therefore functionally unique, as these properties are present in other transmembrane proteoglycans. However, between these conserved regions is the $\mathrm{V}$ (variable) region, each syndecan having a distinct amino acid sequence. These $\mathrm{V}$ regions are, however, conserved across species, for example the $\mathrm{V}$ region of syndecan-1 is almost identical in rodents, pig, primates and avians. The $\mathrm{V}$ regions, however, have been reluctant to reveal their functions, with the possible exception of syndecan-4. Its unusual LGKKPIYKK amino acid sequence interacts with the phospholipid phosphatidylinositol 4,5 bisphosphate, which induces a conformational change in the syndecan [195]. This provides a platform for interaction and activation of protein kinase $\mathrm{C} \alpha$ [196]. There may be several substrates for the kinase, RhoGDI being one of them. This important regulator can sequester, but also target Rho family GTPases to specific intracellular sites [197]. Phosphorylation at serine34 triggers the release of GDP-Rho (but not GDP-Rac or GDP-cdc42) from RhoGDI, which can then be converted to the active GTP-Rho through one or more RhoGEFs, with downstream activation of targets such as Rho kinases, notably ROCK $1[198,199]$. Other potential targets are p190RhoGAP, which may relocalise this Rho inactivator [200]. The net effect is promotion of stress fibres and focal adhesion formation, consistent with previous data suggesting a role for syndecan-4 in this process $[164,167]$.

Very recently, however, another potential substrate has been identified [201]. Evidence suggests that syndecans can regulate the canonical group of transient receptor potential calcium channels. A conserved serine residue [202] adjacent to the TRP domain of the channels can be phosphorylated in a 
PKC-dependent manner, causing channel closure. Therefore, syndecan-4 null fibroblasts have higher resting cytoplasmic calcium levels than wild type counterparts, but removal of TRPC7 by siRNA causes calcium reduction, and concomitant stress fiber formation. Further evidence suggests this principle is common to all the syndecans, and we have shown that it is conserved in the invertebrate, $C$. elegans [201]. The channels may not interact directly with syndecan; in the case of syndecan-4, a complex with TRPC7 and $\alpha$-actinin was observed. This is consistent with previous reports of direct interactions between this actin-associated protein and both syndecan-4 and TRPC6, a very close homolog of TRPC7 [203]. Since calcium is a key regulator of many cellular processes, involving cytoskeletal and transcriptional regulation, it is possible that heparan sulfate-binding ligands can trigger common, localized calcium regulation through the syndecans with impact on the cell adhesion and migration phenotype.

\subsection{Syndecans and Cancer}

While there are few indications that syndecan mutations have a role in tumour progression, many studies have reported alterations in syndecan expression in solid and hematogenous tumours [173, 204]. In most cases, however, it is unclear whether misexpressed syndecans are contributors or bystanders in tumour progression. However, in the case of myeloma, syndecan-1 expression has been causally related to tumour growth and malignancy [205]. In addition, there appears to be an important role for heparanase, an enzyme that cleaves heparan sulfate chains into oligosaccharides that may retain important biological functions [205]. There are now several tumour types where heparanase is implicated in progression and an inhibitor is now in the early stages of clinical trials.

In breast cancer, expression of syndecan-1 is related to poor prognosis, particularly where it is also present in the tumour stroma as well as carcinoma cells [206]. In a mouse model of mammary carcinogenesis, it was shown that syndecan-1 was required for Wnt1 promoted tumour formation [207]. This appears to be related to $\beta$-catenin/TCF signalling since syndecan- 1 was shown to be essential for responsiveness to this important regulator of growth and proliferation [207]. However, in other tumour types, e.g. head/neck and oral squamous carcinomas, loss of syndecan-1 is related to a worse patient outcome. Cell surface syndecan-1 expression at the invasive front had a negative correlation with invasion depth of OSCC tumours. In addition, Farnedi A et al. [208] identified NG2/CSPG4 and syndecan-2 as unique relapse and overall survival prediction factors in head and neck cancer tumour patients.

Clearly there is much to learn regarding syndecans' roles in tumour biology, but likely, redundancy is an important issue. Mice null for syndecan-1, syndecan-4 or even both syndecan-1 and -4 are viable, 
anatomically normal and fertile [201]. Single null mice have postnatal wound repair phenotypes, and the double null has alterations in early stages of epidermal differentiation [201], but overall, these phenotypes are mild. In contrast, deletion of enzymes involved in heparan sulfate synthesis can be severe or embryonic lethal. All this suggests redundancy, an issue that may complicate tumour studies. Only rarely are all four syndecans studied in a single patient sample.

Another complication is that syndecans may not always function independently. Although not yet shown to be co-receptors with DDR proteins, they have been associated with integrins in many cases [168]. In epithelial cells, syndecan-1 has been reported to interact directly with $\alpha v \beta 3$ and $\alpha v \beta 5$ integrins [209]. Moreover, large complexes containing syndecans and growth factor receptors may include integrins and possibly cell-cell adhesion molecules as well (e.g. VE-cadherin in endothelial cells - [210]). Syndecans may therefore aid in translating a growth factor signal into an adhesion response. The region of syndecan-1 ectodomain that interacts with integrins (known as synstatin) can be biologically important, notably in a cancer context. Beauvais et al. [210] showed in human mammary carcinoma cells that synstatin could be a powerful inhibitor. This raises the possibility of new approaches to target tumour cell surface receptors. This may apply to all the human syndecans. Syndecan- 2 may regulate $\beta 1$ integrin indirectly through its ectodomain interaction with CD148, a transmembrane phosphatase [211]. Syndecan-4 associates with integrins at focal adhesions, and influences the size and number of adhesions, with implications for cell migration [167].

\section{Acknowledgements}

HM and JRC acknowledge recent research support from The Danish National Research Foundation, Novo Nordisk Fonden, Lundbeck Fonden and The Danish Council of Natural Sciences; funding from the Medical Research Council UK (Grant G0701121) and the Biotechnology and Biological Sciences Research Council UK (Grant BB/I011226/1) to BL and Norwegian Centre of Excellence grant 223250 to DG are also acknowledged.

\section{Figure legends}

Figure 1. Diagrams of Integrin, CD44, Syndecan and Discoidin Domain Receptors topography. All are transmembrane receptors for ECM molecules, despite quite different structures and modes of ligand binding. 
Figure 2. Structural organisation of the DDRs. The extracellular regions are composed of an $\mathrm{N}$-terminal discoidin homology (DS) domain, a DS-like domain and a juxtamembrane (JM) region. The DDR1 JM region contains $\sim 50$ amino acids, the DDR2 JM region has 30 amino acids. The transmembrane domains (TM) are followed by a large intracellular JM region (up to 170 amino acids in DDR1, 140 amino acids in DDR2) and a C-terminal kinase domain. The plasma membrane is represented by a grey bar. The collagen binding region in the DS domain is indicated in red. Several isoforms of DDR1 exist, which differ in their cytoplasmic regions. The two main isoforms, DDR1a and DDR1b, are shown. The DDR1b region with additional 37 amino acids in the intracellular JM region, relative to DDR1a, is highlighted in light grey. 


\section{References}

[1] V. Bolós, J.M. Gasent, S. López-Tarruella, E. Grande, The dual kinase complex FAK-Src as a promising therapeutic target in cancer, Onco Targets Ther. 24 (2010) 83-97.

[2] X.L. Zhao, J.L. Guan, Focal adhesion kinase and its signaling pathways in cell migration and angiogenesis,. Adv. Drug Deliv. Rev. 63 (2011) 610-615.

[3] P. Paoli, E. Giannoni, P. Chiarugi, Anoikis molecular pathways and its role in cancer progression, Biochim. Biophys. Acta 1833 (2013) 3481-3498.

[4] M.H. Ginsberg, Integrin activation, BMB Rep. 47 (2014) 655-659.

[5] J. Yang, L. Zhu, H. Zhang, J. Hirbawi, K. Fukuda, P. Dwivedi, J. Liu, T. Byzova, E.F. Plow, J. Wu, J. Qin, Conformational activation of talin by RIAM triggers integrin-mediated cell adhesion, Nat. Commun. 5 (2014) 5880.

[6] L.B. Case, M.A. Baird, G. Shtengel, S.L. Campbell, H.F. Hess, M.W. Davidson, C.M. Waterman, Molecular mechanism of vinculin activation and nanoscale spatial organization in focal adhesions, Nat. Cell. Biol. bakin(2015) 880-892.

[7] C.C. Sun, X.J. Qu, Z.H. Gao, Integrins: players in cancer progression and targets in cancer therapy, Anticancer Drugs. 25 (2014) 1107-1121.

[8] M. Schlesinger, G. Bendas, Contribution of very later antigen-4 (VLA-4) integrin to cancer progression and metastasis, Cancer Metastasis Rev. (2015) doi: 10.1007/s10555-014-9545$\mathrm{x}$.

[9] L. Seguin, J.S. Desgrosellier, S.M. Weis, D.A. Cheresh, Integrins and cancer: regulators of cancer stemness, metastasis, and drug resistance, Trends Cell Biol. 25 (2015) 234-240.

[10] D. Naci, K. Vuori, F. Aoudjit, Alpha2beta1 integrin in cancer development and chemoresistance, Semin. Cancer Biol. (2015) S1044-579X(15)00067-X. doi: 10.1016/j.semcancer.2015.08.004.

[11] D.I. Cantor, H.R. Cheruku, E.C. Nice, M.S. Baker, Integrin $\alpha v \beta 6$ sets the stage for colorectal cancer metastasis, Cancer Metastasis Rev. (2015) doi: 10.1007/s10555-015-9591-z.

[12] O.E. Franco, A.K. Shaw, D.W. Strand, S.W. Hayward, Cancer Associated Fibroblasts in Cancer Pathogenesis, Semin. Cell Dev. Biol. 21 (2010) 33-39.

[13] I. Haviv, K. Polyak, W. Qiu, M. Hu, I. Campbell, Origin of carcinoma associated fibroblasts, Cell Cycle 8 (2009) 589-595.

[14] R. Kalluri, M. Zeisberg, Fibroblasts in cancer, Nat. Rev. Cancer 6 (2006) 392-401.

[15] B. Rybinski, J. Franco-Barraza, E. Cukierman, The wound healing, chronic fibrosis, and cancer progression triad, Physiol. Genomics 46 (2014) 223-244. 
[16] A. Östman, M. Augsten, Cancer-associated fibroblasts and tumor growth--bystanders turning into key players, Curr. Opin. Genet. Dev. 19 (2009) 67-73.

[17] K. Pietras, A. Östman, Hallmarks of cancer: interactions with the tumor stroma, Exp. Cell. Res. 316 (2010) 1324-1331.

[18] K.R. Levental, H. Yu, L. Kass, J.N. Lakins, M. Egeblad, J.T. Erler, S.F. Fong, K. Csiszar, A. Giaccia, W. Weninger, M. Yamauchi, D.L. Gasser, V.M. Weaver, Matrix crosslinking forces tumor progression by enhancing integrin signaling, Cell 139 (2009) 891-906.

[19] M.S. Samuel, J.I. Lopez, E.J. McGhee, D.R. Croft, D. Strachan, P. Timpson, J. Munro, E. Schröder, J. Zhou, V.G. Brunton, N. Barker, H. Clevers, O.J. Sansom, K.I. Anderson, V.M. Weaver, M.F. Olson, Actomyosin-mediated cellular tension drives increased tissue stiffness and beta-catenin activation to induce epidermal hyperplasia and tumor growth, Cancer Cell 19 (2011) 776-791.

[20] I. Eke, N. Cordes, Focal adhesions signaling and therapy resitance in cancer, Semin. Cancer Biol. 31 (2015) 65-75.

[21] A.D. Rhim, P.E. Oberstein, D.H. Thomas, E.T. Mirek, C.F. Palermo, S.A. Sastra, E.N. Dekleva, T. Saunders, C.P. Becerra, I.W. Tattersall, C.B. Westphalen, J. Kitajewski, M.G. FernandezBarrena, M.E. Fernandez-Zapico, C. Iacobuzio-Donahue, K.P. Olive, B.Z. Stanger, Stromal elements act to restrain, rather than support, pancreatic ductal adenocarcinoma, Cancer Cell 25 (2014) 735-747.

[22] N.I. Reed, H. Jo, C. Chen, K. Tsujino, T.D. Arnold, W.F. DeGrado, D. Sheppard, The alphavbeta1 integrin plays a critical in vivo role in tissue fibrosis, Sci. Transl. Med. 7 (2015) 288 ra79.

[23] R. Kramann, R.K. Schneider, D.P. DiRocco, F. Machado, S. Fleig, P.A. Bondzie, J.M. Henderson, B.L. Ebert, B.D. Humphreys, Perivascular Gli1+ progenitors are key contributors to injury-induced organ fibrosis, Cell Stem Cell 16 (2015) 51-66.

[24] C.P. Ng, B. Hinz, M.A. Swartz, Interstitial fluid flow induces myofibroblast differentiation and collagen alignement in vitro, J. Cell Sci. 118(Pt20) (2005) 4731-4739.

[25] P.D. Arora, N. Natani, C.A. McCulloch, The compliance of collagen gels regulates transforming growth factor-beta induction of alpha-smooth muscle actin in fibroblasts, Am. J. Pathol. 154 (1999) 871-882.

[26] E.K. Honda, K. Yoshida, H. Munakata, Transforming growth factor-beta upregulates the expression of intergrin and related proteinsin MRC-5 human myofibroblasts, Tohoku J. Exp. Med. 220 (2010) 319-327. 
[27] M Kohan, A.F. Muro, E.S. White, N. Berkman, EDA-containing cellular fibronectin induces fibroblast differentiation through binding to alpha4beta7 integrin receptor and MAPK/Erk 1/2-dependent signaling, FASEB J. 24 (2010) 4503-4512.

[28] J.S. Bakin, K Nakayama, C.D. Gilbert, Visual responses in monkey areas V1 and V2 to threedimensional surface configurations, J. Neurosci. 20 (2000) 8188-8198.

[29] D.M. Ramos, D.Dang, S. Sadler, The role of the integrin alphav beta6 in regulating the epithelial to mesenchymal transition in oral cancer, Anticancer Res. 29 (2009) 125-130.

[30] Y. Nakayama, S. Kon, D. Kuritaki, J. Morimoto, Y. Matsui, T. Uede, Blockade of interaction of alpha9 integrin with its ligands hinders the formation of granulation in cutaneous wound healing, Lab. Invest. 90 (2010) 881-894.

[31] C. Danussi, A. Petrucco, B. Wassermann, E. Pivetta, T.M. Modica, L. Del Bel Belluz, A. Colombatti, P. Spessotto, EMILIN1- $\alpha 4 / \alpha 9$ integrin interaction inhibits dermal fibroblasts and keratinocyte proliferation, J. Cell Biol. 195 (2011) 131-145.

[32] Y. Asano, H. Ihn, K. Yamane, M. Jinnin, K. Tamaki, Increased expression of integrin alphavbeta5 induces the myoblastic differentiationof dermal fibroblasts, Am. J. Pathol. 168 (2006) 499-510.

[33] S.J. Payne, L. Jones, Influence of the tumor microenvironment on angiogenesis, Future Oncol. 7 (2011) 395-408.

[34] P.D. Arora, Y. Wang, P.A. Janmey, A. Bresnick, H.L. Yin, C.A. McCulloch, Gelsolin and nonmuscle myosin IIA interact to mediate calcium-regulated collagen phagocytosis, J. Biol. Chem. 286 (2011) 34184-34198.

[35] A. Rodriguez, J. Karen, H. Gardner, B. Gerdin, K. Rubin, C. Sundberg, Integrin alpha1beta1 is involved in the differentiation into myofibroblasts in adult reactive tissues in vivo, J. Cell. Mol. Med. 13 (2009) 3449-3462.

[36] J.E. Wu, S.A. Santoro, Complex patterns of expression suggest extensive roles for the a2b1 integrin in murine development, Dev. Dyn. 199 (1994) 292-314.

[37] A. Pozzi, P.E. Moberg, L.A. Miles, S. Wagner, P. Soloway, H.A. Gardner, Elevated matrix metalloprotease and angiostatin levels in integrin a1 knockout mice cause reduced tumor vascularization, Proc. Natl. Acad. Sci. U S A. 97 (2000) 2202-2207.

[38] M.E. Hemler, J.G. Jacobson, J.L. Strominger, Biochemical characterization of VLA-1 and VLA2. Cell surface heterodimers on activated T cells, J. Biol. Chem. 260 (1985b) 15246-15252.

[39] L. Camper, K. Holmvall, C. Wängnerud, A. Aszódi, E. Lundgren-Akerlund, Distribution of the collagen-binding integrin alpha10beta1 during mouse development, Cell Tissue Res. 306 (2001) 107-116. 
[40] A.K. Wenke, C. Kjellman, E. Lundgren-Akerlund, C. UhImann, N.K. Haass, M. Herlyn, A.K. Bosserhoff, Expression of integrin alpha10 is induced in malignant melanoma, Cell. Oncol. 29 (2007) 373-86.

[41] J.N. Schulz, C. Zeltz, I.W.Sørensen, M. Barczyk, S. Carracedo, R. Hallinger, A. Niehoff, B. Eckes, D. Gullberg, Reduced granulation tissue and wound strength in the absence of alpha11beta1 integrin, J. Invest. Dermatol. 135 (2015) 1435-1444.

[42] R. Navab, D. Strumpf, C. To, E. Pasko, K.S. Kim, C.J. Park, J. Hai, J. Liu, J. Jonkman, M. Barczyk, B. Bandarchi, Y.H. Wang, K. Venkat, E. Ibrahimov, N.A. Pham, C. Ng, N. Radulovich, C.Q. Zhu, M. Pintilie, D. Wang, A. Lu, I. Jurisical, G.C. Walker, D. Gullberg, M.S. Tsao, Integrin alpha11beta1 regulates cancer stromal stiffness and promotes tumorigenicity and metastasis in non-small cell lung cancer, Oncogene (2015) doi: 10.1038/onc.

[43] S. Carracedo, N. Lu, S.N. Popova, R. Jonsson, B. Eckes, D. Gullberg, The fibroblast integrin alpha11beta1 is induced in a mechanosensitive manner involving activin $A$ and regulates myofibroblast differentiation, J. Biol. Chem. 285 (2010) 10434-10445.

[44] I. Talior-Volodarsky, K.A. Connelly, P.D. Arora, D. Gullberg, C.A. McCulloch, alpha11 integrin stimulates myofibroblast differentiation in diabetic cardiomyopathy, Cardiovasc. Res. 96 (2012) 265-275.

[45] N. Lu, T.V. Karlsen, R.K. Reed, M. Kusche-Gullberg, D. Gullberg, Fibroblast alpha11beta1 integrin regulates tensional homeostasis in fibroblast/A549 carcinoma heterospheroids, PLoS One 9 (2014) e103173.

[46] I. Talior-Volodarsky, P.D. Arora, Y. Wang, C. Zeltz, K.A. Connelly, D. Gullberg, C.A. McCulloch, Glycated collagen induces alpha11 integrin expression through TGF-beta2 and Smad3, J. Cell. Physiol. 230 (2015) 327-336.

[47] C.Q. Zhu, S.N. Popova, E.R. Brown, D. Barsyte-Lovejoy, R. Navab, W. Shih, M. Li, M. Lu, I. Jurisica, L.Z. Penn, D. Gullberg, M.S. Tsao, Integrin alpha 11 regulates IGF2 expression in fibroblasts to enhance tumorigenicity of human non-small-cell lung cancer cells, Proc. Natl. Acad. Sci. U S A. 104 (2007) 11754-11759.

[48] J.M. Westcott, A.M. Prechtl, E.A. Maine, T.T Dang, M.A. Esparza, H. Sun, Y. Zhou, Y. Xie, G.W. Pearson, An epigenetically distinct breast cancer cell subpopulation promotes collective invasion, J. Clin. Invest. 125 (2015) 1927-1943.

[49] S. Liu, S.W. Xu, K. Blumbach, M. Eastwood, C.P. Denton, B. Eckes, T. Krieg, D.J. Abraham, a. Leask, Expression of integrin beta1 by fibroblasts is required for tissue repair in vivo, J. Cell. Sci. 123 (2010) 3674-3682.

[50] S. Astrof. R.O. Hynes, Fibronectins in vascular morphogenesis, Angiogenesis 12 (2009) 165175. 
[51] A.V. Shinde, C. Bystroff, C. Wang, M.G. Vogelezang, P.A. Vincent, P.O. Hynes, L. Van De Water, Identification of the peptide sequences within the EIIIA (EDA) segment of fibronectin that mediate integrin alpha9beta1-dependent cellular activities, J. Biol. Chem. 283 (2008) 2858-2870.

[52] R. Manabe, N. Ohe T. Maeda, T. Fukuda, K. Sekiguchi, Modulation of cell-adhesive activity of fibronectin by the alternatively spliced EDA segment, J. Cell. Biol. 139 (1997) 295-307.

[53] G. Serini, M.L. Bochaton-Pialla, P. Ropraz, A. Geinoz, L. Borsi, L. Zardi, G. Gabbiani, The fibronectin domain ED-A is crucial for myofibroblastic phenotype induction by transforming growth factor-beta1, J. Cell. Biol. 142 (1998) 873-881.

[54] F. Arslan, M.B. Smeets, P.W. Riem Vis, J.C. Karper, P.H. Quax, L.G. Bongartz, J.H. Peters, I.E. Hoefer, P.A. Doevendans, G. Pasterkamp, D.P. de Kleijn, Lack of fibronectin-EDA promotes survival and prevents adverse remodeling and heart function deterioration after myocardial infarction, Circ. Res. 108 (2011) 582-592.

[55] R.M. Kelsh, P.J. McKeown-Longo, R.A. Clark, EDA fibronectin in keloids create a vicious cycle of fibrotic tumor formation, J. Invest. Dermatol. 135 (2015) 1714-1718.

[56] N.C. Henderson, T.D. Arnold, Y. Katamura, M.M. Giacomini, J.D. Rodriguez, J.H. McCarty, A. Pellicoro, E. Raschperger, C. Betsholtz, P.G. Ruminski, D.W. Griggs, M.J. Prinsen, J.J. Maher, J.P. Iredale, A. Lacy-Hulbert, R.H. Adams, D. Sheppard, Targeting of alphav integrin identifies a core molecular pathway that regulates fibrosis in several organs, Nat. Med. 19 (2013) 1617-1624.

[57] P.J. Wipff, D.B. Rifkin, J.J. Meister, B. Hinz, Myofibroblast contraction activates latent TGFbeta1 from the extracellular matrix, J. Cell. Biol. 179 (2007) 1311-1323.

[58] H. Kitamura, S. Cambier, S. Somanath, T. Barker, S. Minagawa, J. Markovics, A. Goodsell, J. Publicover, L. Reichardt, D. Jablons, P. Wolters, A. Hill, J.D. Marks, J. Lou, J.F. Pittet, J. Gauldie, J.L. Baron, S.L. Nishimura, Mouse and human lung fibroblasts regulate dendritic cell trafficking, airway inflammation, and fibrosis through integrin $\alpha v \beta 8$-mediated activation of TGF- $\beta$, J. Clin. Invest. 121 (2011) 2863-2875.

[59] F. Klingberg, M.L. Chow, A. Koehler, S. Boo, L. Buscemi, T.M. Quinn, M. Costell, B.A. Alman, E. Genot, B. Hinz, Prestress in the extracellular matrix sensitizes latent TGF-beta1 for activation, J. Cell. Biol. 207 (2014) 283-297.

[60] S. Honda, H. Shirotani-Ikejima, S. Tadokoro, Y. Maeda, T. Kinoshita, Y. Tomiyama, T. Miyata, Integrin-linked kinase associated with integrin activation, Blood 113 (2009) 5304-5313.

[61] B.C. Ozdemir, T. Pentcheva-Hoang, J.L. Carstens, X. Zheng, C.C. Wu, T.R. Simpson, H. Laklai, H. Sugimoto, C. Kahlert, S.V. Novitskiy, A. De Jesus-Acosta, P. Sharma, P. Heidari, U. Mahmood, L. Chin, H.L. Moses, V.M. Weaver, A. Maitra, J.P. Allison, V.S. LeBleu, R. Kalluri, 
Depletion of carcinoma-associated fibroblasts and fibrosis induces immunosuppression and accelerates pancreas cancer with reduced survival, Cancer Cell 25 (2014) 719-734.

[62] B. Hinz, Formation and function of the myofibroblast during tissue repair, J. Invest. Dermatol. 127 (2007) 526-537.

[63] S. Liu, R. Taghavi, A. Leask, Connective tissue growth factor is induced in bleomycin-induced skin scleroderma, J. Cell. Commun. Signal. 4 (2010) 25-30.

[64] R.R. Driskell, B.M. Lichtenberger, E. Hoste, K. Kretzschmar, B.D. Simons, M. Charalambous, S.R. Ferron, Y. Herault, G. Pavlovic, A.C. Ferguson-Smith, F.M. Watt, Distinct fibroblast lineages determine dermal architecture in skin development and repair, Nature 504 (2013) 277-281.

[65] Y. Rinkevich, G.G. Walmsley, M.S. Hu, Z.N. Maan, A.M. Newman, M. Drukker, M. Januszyk, G.W. Krampitz, G.C. Gurtner, H.P. Lorenz, I.L. Weissman, M.T. Longaker, Skin fibrosis. Identification and isolation of a dermal lineage with intrinsic fibrogenic potential, Science 348 (2015) aaa2151.

[66] R.M. Bremnes, K. Al-Shibli, T. Donnem, R. Sirera, S. Al-Saad, S. Andersen, H. Stenvold, C. Camps, L.T. Busund, The role of tumor stroma in cancer progression and prognosis: emphasis on carcinoma-associated fibroblasts and non-small cell lung cancer, J. Thorac. Oncol. 6 (2011) 209-217.

[67] S. Liu, M. Kapoor, C.P. Denton, D.J. Abraham, A. Leask, Loss of beta1 integrin in mouse fibroblasts results in resistance to skin scleroderma in a mouse model, Arthritis Rheum. 60 (2009) 2817-2821.

[68] M. Shimoda, K.T. Mellody, A. Orimo, Carcinoma-associated fibroblasts are a rate-limiting determinant for tumour progression, Semin. Cell. Dev. Biol. 21 (2010) 19-25.

[69] K. Pietras, J. Pahler, G. Bergers, D. Hanahan, Functions of paracrine PDGF signaling in the proangiogenic tumor stroma revealed by pharmacological targeting, PLoS Med. 5 (2008) e19.

[70] S. Hooper, C. Gaggioli, E. Sahai, A chemical biology screen reveals a role for Rab21mediated control of actomyosin contractility in fibroblast-driven cancer invasion, $\mathrm{Br}$. J. Cancer 102 (2010) 392-402.

[71] J.T. Erler, K.L. Bennewith, M. Nicolau, N. Dornhöfer, C. Kong, Q.T. Le, J.T. Chi, S.S. Jeffrey, A.J. Giaccia, Lysyl oxidase is essential for hypoxia-induced metastasis, Nature 440 (2006) $1222-1226$.

[72] A.M. Baker, D. Bird, G. Lang, T.R. Cox, J.T. Erler, Lysyl oxidase enzymatic function increases stiffness to drive colorectal cancer progression through FAK, Oncogene 32 (2013) 18631868. 
[73] B.W. Miller, J.P. Morton, M. Pinese, G. Saturno, N.B. Jamieson, E. McGhee, P. Timpson, J. Leach, L. McGarry, E. Shanks, P. Bailey, D. Chang, K. Oien, S. Karim, A. Au, C. Steele, C.R. Carter, C. McKay, K. Anderson, T.R. Evans, R. Marais, C. Springer, A. Biankin, J.T. Erler, O.J. Sansom, Targeting the LOX/hypoxia axis reverses many of the features that make pancreatic cancer deadly: inhibition of LOX abrogates metastasis and enhances drug efficacy, EMBO Mol. Med. 7 (2015) 1063-1076.

[74] B. Hinz, The extracellular matrix and transforming growth factor-beta1: Tale of a strained relationship, Matrix Biol. (2015) doi: 10.1016/j.

[75] C. Gaggioli, S. Hooper, C. Hidalgo-Carcedo, R. Grosse, J.F. Marshall, K. Harrington, E. Sahai, Fibroblast-led collective invasion of carcinoma cells with differing roles for RhoGTPases in leading and following cells, Nat. Cell. Biol. 9 (2007) 1392-1400.

[76] S. Medjkane, C. Perez-Sanchez, C. Gaggioli, E. Sahai, R. Treisman, Myocardin-related transcription factors and SRF are required for cytoskeletal dynamics and experimental metastasis, Nat. Cell. Biol. 11 (2009) 257-268.

[77] V. Sanz-Moreno, C. Gaggioli, M. Yeo, J. Albrengues, F. Wallberg, A. Viros, S. Hooper, R. Mitter, C.C. Féral, M. Cook, J. Larkin, R. Marais, G. Meneguzzi, E. Sahai, C.J. Marshall, ROCK and JAK1 signaling cooperate to control actomyosin contractility in tumor cells and stroma cancer, Cell 20 (2011) 229-245.

[78] F. Calvo, N. Ege, A. Grande-Garcia, S. Hooper, R.P. Jenkins, S.I. Chaudhry, K. Harrington, P. Williamson, E. Moeendarbary, G. Charras, E. Sahai, Mechanotransduction and YAPdependent matrix remodelling is required for the generation and maintenance of cancerassociated fibroblasts, Nat. Cell. Biol. 15 (2013) 637-646.

[79] D.G. Duda, A.M. Duyverman, M. Kohno, M. Snuderl, E.J. Steller, D. Fukumura, R.K. Jain, Malignant cells facilitate lung metastasis by bringing their own soil, Proc. Natl. Acad. Sci. U S A. 107 (2010) 21677-21682.

[80] H.L. Fu, R.R. Valiathan, R. Arkwright, A. Sohail, C. Mihai, M. Kumarasiri, K.V. Mahasenan, S. Mobashery, P. Huang, G. Agarwal, R. Fridman, Discoidin domain receptors: unique receptor tyrosine kinases in collagen-mediated signaling, J. Biol. Chem. 288 (2013) 7430-7437.

[81] B. Leitinger, Discoidin domain receptor functions in physiological and pathological conditions, Int. Rev. Cell Mol. Biol. 310 (2014) 39-87.

[82] F. Carafoli, M.C. Mayer, K. Shiraishi, M.A. Pecheva, L.Y. Chan, R. Nan, B. Leitinger, E. Hohenester, Structure of the discoidin domain receptor 1 extracellular region bound to an inhibitory Fab fragment reveals features important for signaling, Structure 20 (2012) 688697. 
[83] R.R. Valiathan, M. Marco, B. Leitinger, C.G. Kleer, R. Fridman, Discoidin domain receptor tyrosine kinases: new players in cancer progression, Cancer Metastasis Rev. 31 (2012) 295321.

[84] C.M. Borza, A. Pozzi, Discoidin domain receptors in disease, Matrix Biol. 34 (2014) 185-192.

[85] W. Vogel, G.D. Gish, F. Alves, T. Pawson, The discoidin domain receptor tyrosine kinases are activated by collagen, Mol. Cell 1 (1997) 13-23.

[86] A. Shrivastava, C. Radziejewski, E. Campbell, L. Kovac, M. McGlynn, T.E. Ryan, S. Davis, M.P. Goldfarb, D.J. Glass, G. Lemke, G.D. Yancopoulos, An orphan receptor tyrosine kinase family whose members serve as nonintegrin collagen receptors, Mol. Cell 1 (1997) 25-34.

[87] B. Leitinger, Molecular analysis of collagen binding by the human discoidin domain receptors, DDR1 and DDR2. Identification of collagen binding sites in DDR2, J. Biol. Chem. 278 (2003) 16761-16769.

[88] A.D. Konitsiotis, N. Raynal, D. Bihan, E. Hohenester, R.W. Farndale, B. Leitinger, Characterization of high affinity binding motifs for the discoidin domain receptor DDR2 in collagen, J. Biol. Chem. 283 (2008) 6861-6868.

[89] H. Xu, N. Raynal, S. Stathopoulos, J. Myllyharju, R.W. Farndale, B. Leitinger, Collagen binding specificity of the discoidin domain receptors: binding sites on collagens II and III and molecular determinants for collagen IV recognition by DDR1, Matrix Biol. 30 (2011) 16-26.

[90] O. Ichikawa, M. Osawa, N. Nishida, N. Goshima, N. Nomura, I. Shimada, Structural basis of the collagen-binding mode of discoidin domain receptor 2, EMBO J., 26 (2007) 4168-4176.

[91] F. Carafoli, D. Bihan, S. Stathopoulos, A.D. Konitsiotis, M. Kvansakul, R.W. Farndale, B. Leitinger, E. Hohenester, Crystallographic insight into collagen recognition by discoidin domain receptor 2, Structure 17 (2009) 1573-1581.

[92] M.A. Lemmon, J. Schlessinger, Cell signaling by receptor tyrosine kinases, Cell 141 (2010) 1117-1134.

[93] N.A. Noordeen, F. Carafoli, E. Hohenester, M.A. Horton, B. Leitinger, A transmembrane leucine zipper is required for activation of the dimeric receptor tyrosine kinase DDR1, J. Biol. Chem. 281 (2006) 22744-22751.

[94] C. Mihai, M. Chotani, T.S. Elton, G. Agarwal, Mapping of DDR1 distribution and oligomerization on the cell surface by FRET microscopy, J. Mol. Biol. 385 (2009) 432-445.

[95] H. Xu, T. Abe, J.K. Liu, I. Zalivina, E. Hohenester, B. Leitinger, Normal activation of discoidin domain receptor 1 mutants with disulfide cross-links, insertions, or deletions in the extracellular juxtamembrane region: mechanistic implications, J. Biol. Chem. 289 (2014) 13565-13574. 
[96] K. Ikeda, L.H. Wang, R. Torres, H. Zhao, E. Olaso, F.J. Eng, P. Labrador, R. Klein, D. Lovett, G.D. Yancopoulos, S.L. Friedman, H.C. Lin, Discoidin domain receptor 2 interacts with Src and Shc following its activation by type I collagen, J. Biol. Chem. 277 (2002) 19206-19212.

[97] D.H. Koo, C. McFadden, Y. Huang, R. Abdulhussein, M. Friese-Hamim, W.F. Vogel, Pinpointing phosphotyrosine-dependent interactions downstream of the collagen receptor DDR1, FEBS Lett. 580 (2006) 15-22.

[98] V. Abbonante, C. Gruppi, D. Rubel, O. Gross, R. Moratti, A. Balduini, Discoidin domain receptor 1 protein is a novel modulator of megakaryocyte-collagen interactions, J. Biol. Chem. 288 (2013) 16738-16746.

[99] C.Z. Wang, H.W. Su, Y.C. Hsu, M.R. Shen, M.J. Tang, A Discoidin Domain Receptor 1/SHP-2 Signaling Complex Inhibits \{alpha\}2beta1-Integrin-mediated Signal Transducers and Activators of Transcription 1/3 Activation and Cell Migration, Mol. Biol. Cell 17 (2006) 28392852.

[100] E. Faraci-Orf, C. McFadden, W.F. Vogel, DDR1 signaling is essential to sustain Stat5 function during lactogenesis, J. Cell. Biochem. 97 (2006) 109-121.

[101] L.K. Iwai, L.S. Payne, M.T. Luczynski, F. Chang, H. Xu, R.W. Clinton, A. Paul, E.A. Esposito, S. Gridley, B. Leitinger, K.M. Naegle, P.H. Huang, Phosphoproteomics of collagen receptor networks reveals SHP-2 phosphorylation downstream of wild-type DDR2 and its lung cancer mutants, Biochem. J. 454 (2013) 501-513.

[102] K.K. Lu, D. Trcka, M.P. Bendeck, Collagen stimulates discoidin domain receptor 1-mediated migration of smooth muscle cells through Src, Cardiovasc. Pathol. 20 (2011) 71-76.

[103] H.N. Hilton, P.M. Stanford, J. Harris, S.R. Oakes, W. Kaplan, R.J. Daly, C.J. Ormandy, KIBRA interacts with discoidin domain receptor 1 to modulate collagen-induced signalling, Biochim. Biophys. Acta 1783 (2008) 383-393.

[104] C.A. Curat, W.F. Vogel, Discoidin domain receptor 1 controls growth and adhesion of mesangial cells, J. Am. Soc. Nephrol. 13 (2002) 2648-2656.

[105] S. Ghosh, K. Ashcraft, M.J. Jahid, C. April, C.M. Ghajar, J. Ruan, H. Wang, M. Foster, D.C. Hughes, A.G. Ramirez, T. Huang, J.B. Fan, Y. Hu, R. Li, Regulation of adipose oestrogen output by mechanical stress, Nat. Commun. 4 (2013) 1821.

[106] L. Xu, H. Peng, S. Glasson, P.L. Lee, K. Hu, K. Ijiri, B.R. Olsen, M.B. Goldring, Y. Li, Increased expression of the collagen receptor discoidin domain receptor 2 in articular cartilage as a key event in the pathogenesis of osteoarthritis, Arthritis Rheum. 56 (2007) 2663-2673.

[107] B. Poudel, H.H. Ki, Y.M. Lee, D.K. Kim, Induction of IL-12 production by the activation of discoidin domain receptor 2 via NF-kappaB and JNK pathway, Biochem. Biophys. Res. Commun. 434 (2013) 584-588. 
[108] K.L. Lin, C.H. Chou, S.C. Hsieh, S.Y. Hwa, M.T. Lee, F.F. Wang, Transcriptional upregulation of DDR2 by ATF4 facilitates osteoblastic differentiation through p38 MAPK-mediated Runx2 activation, J. Bone Miner. Res. 25 (2010) 2489-2503.

[109] Y. Zhang, J. Su, J. Yu, X. Bu, T. Ren, X. Liu, L. Yao, An essential role of discoidin domain receptor 2 (DDR2) in osteoblast differentiation and chondrocyte maturation via modulation of Runx2 activation, J. Bone Miner. Res. 26 (2011) 604-617.

[110] C. Hidalgo-Carcedo, S. Hooper, S.I. Chaudhry, P. Williamson, K. Harrington, B. Leitinger, E. Sahai, Collective cell migration requires suppression of actomyosin at cell-cell contacts mediated by DDR1 and the cell polarity regulators Par3 and Par6, Nat. Cell Biol. 13 (2011) 49-58.

[111] K. Valencia, C. Ormazabal, C. Zandueta, D. Luis-Ravelo, I. Anton, M.J. Pajares, J. Agorreta, L.M. Montuenga, S. Martinez-Canarias, B. Leitinger, F. Lecanda, Inhibition of collagen receptor discoidin domain receptor-1 (DDR1) reduces cell survival, homing, and colonization in lung cancer bone metastasis, Clin. Cancer Res. 18 (2012) 969-980.

[112] F.Z. Cader, M. Vockerodt, S. Bose, E. Nagy, M.A. Brundler, P. Kearns, P.G. Murray, The EBV oncogene LMP1 protects lymphoma cells from cell death through the collagen-mediated activation of DDR1, Blood 122 (2013) 4237-4245.

[113] H.G. Kim, S.Y. Hwang, S.A. Aaronson, A. Mandinova, S.W. Lee, DDR1 receptor tyrosine kinase promotes prosurvival pathway through Notch1 activation, J. Biol. Chem. 286 (2011) $17672-17681$.

[114] Z.X. Jian, J. Sun, W. Chen, H.S. Jin, J.H. Zheng, Y.L. Wu, Involvement of discoidin domain 1 receptor in recurrence of hepatocellular carcinoma by genome-wide analysis, Med. Oncol. 29 (2012) 3077-3082.

[115] K. Zhang, C.A. Corsa, S.M. Ponik, J.L. Prior, D. Piwnica-Worms, K.W. Eliceiri, P.J. Keely, G.D. Longmore, The collagen receptor discoidin domain receptor 2 stabilizes SNAIL1 to facilitate breast cancer metastasis, Nat. Cell Biol. 15 (2013) 677-687.

[116] P.S. Hammerman, M.L. Sos, A.H. Ramos, C. Xu, A. Dutt, W. Zhou, L.E. Brace, B.A. Woods, W. Lin, J. Zhang, X. Deng, S.M. Lim, S. Heynck, M. Peifer, J.R. Simard, M.S. Lawrence, R.C. Onofrio, H.B. Salvesen, D. Seidel, T. Zander, J.M. Heuckmann, A. Soltermann, H. Moch, M. Koker, F. Leenders, F. Gabler, S. Querings, S. Ansen, E. Brambilla, C. Brambilla, P. Lorimier, O.T. Brustugun, A. Helland, I. Petersen, J.H. Clement, H. Groen, W. Timens, H. Sietsma, E. Stoelben, J. Wolf, D.G. Beer, M.S. Tsao, M. Hanna, C. Hatton, M.J. Eck, P.A. Janne, B.E. Johnson, W. Winckler, H. Greulich, A.J. Bass, J. Cho, D. Rauh, N.S. Gray, K.K. Wong, E.B. Haura, R.K. Thomas, M. Meyerson, Mutations in the DDR2 kinase gene identify a novel therapeutic target in squamous cell lung cancer, Cancer Discov. 1 (2011) 78-89. 
[117] L.S. Payne, P.H. Huang, The pathobiology of collagens in glioma, Mol. Cancer Res. 11 (2013) $1129-1140$.

[118] H. Davies, C. Hunter, R. Smith, P. Stephens, C. Greenman, G. Bignell, J. Teague, A. Butler, S. Edkins, C. Stevens, A. Parker, S. O'Meara, T. Avis, S. Barthorpe, L. Brackenbury, G. Buck, J. Clements, J. Cole, E. Dicks, K. Edwards, S. Forbes, M. Gorton, K. Gray, K. Halliday, R. Harrison, K. Hills, J. Hinton, D. Jones, V. Kosmidou, R. Laman, R. Lugg, A. Menzies, J. Perry, R. Petty, K. Raine, R. Shepherd, A. Small, H. Solomon, Y. Stephens, C. Tofts, J. Varian, A. Webb, S. West, S. Widaa, A. Yates, F. Brasseur, C.S. Cooper, A.M. Flanagan, A. Green, M. Knowles, S.Y. Leung, L.H. Looijenga, B. Malkowicz, M.A. Pierotti, B.T. Teh, S.T. Yuen, S.R. Lakhani, D.F. Easton, B.L. Weber, P. Goldstraw, A.G. Nicholson, R. Wooster, M.R. Stratton, P.A. Futreal, Somatic mutations of the protein kinase gene family in human lung cancer, Cancer Res. 65 (2005) 7591-7595.

[119] C.E. Ford, S.K. Lau, C.Q. Zhu, T. Andersson, M.S. Tsao, W.F. Vogel, Expression and mutation analysis of the discoidin domain receptors 1 and 2 in non-small cell lung carcinoma, Br. J. Cancer 96 (2007) 808-814.

[120] L. Ding, G. Getz, D.A. Wheeler, E.R. Mardis, M.D. McLellan, K. Cibulskis, C. Sougnez, H. Greulich, D.M. Muzny, M.B. Morgan, L. Fulton, R.S. Fulton, Q. Zhang, M.C. Wendl, M.S. Lawrence, D.E. Larson, K. Chen, D.J. Dooling, A. Sabo, A.C. Hawes, H. Shen, S.N. Jhangiani, L.R. Lewis, O. Hall, Y. Zhu, T. Mathew, Y. Ren, J. Yao, S.E. Scherer, K. Clerc, G.A. Metcalf, B. Ng, A. Milosavljevic, M.L. Gonzalez-Garay, J.R. Osborne, R. Meyer, X. Shi, Y. Tang, D.C. Koboldt, L. Lin, R. Abbott, T.L. Miner, C. Pohl, G. Fewell, C. Haipek, H. Schmidt, B.H. Dunford-Shore, A. Kraja, S.D. Crosby, C.S. Sawyer, T. Vickery, S. Sander, J. Robinson, W. Winckler, J. Baldwin, L.R. Chirieac, A. Dutt, T. Fennell, M. Hanna, B.E. Johnson, R.C. Onofrio, R.K. Thomas, G. Tonon, B.A. Weir, X. Zhao, L. Ziaugra, M.C. Zody, T. Giordano, M.B. Orringer, J.A. Roth, M.R. Spitz, Wistuba, II, B. Ozenberger, P.J. Good, A.C. Chang, D.G. Beer, M.A. Watson, M. Ladanyi, S. Broderick, A. Yoshizawa, W.D. Travis, W. Pao, M.A. Province, G.M. Weinstock, H.E. Varmus, S.B. Gabriel, E.S. Lander, R.A. Gibbs, M. Meyerson, R.K. Wilson, Somatic mutations affect key pathways in lung adenocarcinoma, Nature 455 (2008) 1069-1075.

[121] V. Pitini, C. Arrigo, C. Di Mirto, P. Mondello, G. Altavilla, Response to dasatinib in a patient with SQCC of the lung harboring a discoid-receptor-2 and synchronous chronic myelogenous leukemia, Lung Cancer 82 (2013) 171-172.

[122] S.J. An, Z.H. Chen, J. Su, X.C. Zhang, W.Z. Zhong, J.J. Yang, Q. Zhou, X.N. Yang, L. Huang, J.L. Guan, Q. Nie, H.H. Yan, T.S. Mok, Y.L. Wu, Identification of enriched driver gene alterations 
in subgroups of non-small cell lung cancer patients based on histology and smoking status, PLoS One 7 (2012) e40109.

[123] L. Miao, Y. Wang, S. Zhu, M. Shi, Y. Li, J. Ding, J. Yang, Q. Ye, H. Cai, D. Zhang, H. Liu, Y. Song, Identification of novel driver mutations of the discoidin domain receptor 2 (DDR2) gene in squamous cell lung cancer of Chinese patients, BMC Cancer 14 (2014) 369.

[124] K. Konig, M. Peifer, J. Fassunke, M.A. Ihle, H. Kunstlinger, C. Heydt, K. Stamm, F. Ueckeroth, C. Vollbrecht, M. Bos, M. Gardizi, M. Scheffler, L. Nogova, F. Leenders, K. Albus, L. Meder, K. Becker, A. Florin, U. Rommerscheidt-Fuss, J. Altmuller, M. Kloth, P. Nurnberg, T. Henkel, S.E. Bikar, M.L. Sos, W.J. Geese, L. Strauss, Y.D. Ko, U. Gerigk, M. Odenthal, T. Zander, J. Wolf, S. Merkelbach-Bruse, R. Buettner, L.C. Heukamp, Implementation of Amplicon Parallel Sequencing Leads to Improvement of Diagnosis and Therapy of Lung Cancer Patients, J. Thorac. Oncol. 10 (2015) 1049-1057.

[125] Y. Bai, J.Y. Kim, J.M. Watters, B. Fang, F. Kinose, L. Song, J.M. Koomen, J.K. Teer, K. Fisher, Y.A. Chen, U. Rix, E.B. Haura, Adaptive responses to dasatinib-treated lung squamous cell cancer cells harboring DDR2 mutations, Cancer Res. 74 (2014) 7217-7228.

[126] C.W. Murray, V. Berdini, I.M. Buck, M.E. Carr, A. Cleasby, J.E. Coyle, J.E. Curry, J.E. Day, P.J. Day, K. Hearn, A. Iqbal, L.Y. Lee, V. Martins, P.N. Mortenson, J.M. Munck, L.W. Page, S. Patel, S. Roomans, K. Smith, E. Tamanini, G. Saxty, Fragment-Based Discovery of Potent and Selective DDR1/2 Inhibitors, ACS Med. Chem. Lett. 6 (2015) 798-803.

[127] S.H. Yang, H.A. Baek, H.J. Lee, H.S. Park, K.Y. Jang, M.J. Kang, D.G. Lee, Y.C. Lee, W.S. Moon, M.J. Chung, Discoidin domain receptor 1 is associated with poor prognosis of non-small cell lung carcinomas, Oncology Rep. 24 (2010) 311-319.

[128] L. Miao, S. Zhu, Y. Wang, Y. Li, J. Ding, J. Dai, H. Cai, D. Zhang, Y. Song, Discoidin domain receptor 1 is associated with poor prognosis of non-small cell lung cancer and promotes cell invasion via epithelial-to-mesenchymal transition, Med. Oncol. 30 (2013) 626.

[129] K. Rikova, A. Guo, Q. Zeng, A. Possemato, J. Yu, H. Haack, J. Nardone, K. Lee, C. Reeves, Y. Li, Y. Hu, Z. Tan, M. Stokes, L. Sullivan, J. Mitchell, R. Wetzel, J. Macneill, J.M. Ren, J. Yuan, C.E. Bakalarski, J. Villen, J.M. Kornhauser, B. Smith, D. Li, X. Zhou, S.P. Gygi, T.L. Gu, R.D. Polakiewicz, J. Rush, M.J. Comb, Global survey of phosphotyrosine signaling identifies oncogenic kinases in lung cancer, Cell 131 (2007) 1190-1203.

[130] Q. Xiao, Y. Jiang, Q. Liu, J. Yue, C. Liu, X. Zhao, Y. Qiao, H. Ji, J. Chen, G. Ge, Minor Type IV Collagen alpha5 Chain Promotes Cancer Progression through Discoidin Domain Receptor-1, PLoS Genet. 11 (2015) e1005249.

[131] W.F. Vogel, A. Aszodi, F. Alves, T. Pawson, Discoidin domain receptor 1 tyrosine kinase has an essential role in mammary gland development, Mol. Cell. Biol. 21 (2001) 2906-2917. 
[132] M. Koh, Y. Woo, R.R. Valiathan, H.Y. Jung, S.Y. Park, Y.N. Kim, H.R. Kim, R. Fridman, A. Moon, Discoidin domain receptor 1 is a novel transcriptional target of ZEB1 in breast epithelial cells undergoing H-Ras-induced epithelial to mesenchymal transition, Int. J. Cancer 136 (2015) E508-520.

[133] K.T. Barker, J.E. Martindale, P.J. Mitchell, T. Kamalati, M.J. Page, D.J. Phippard, T.C. Dale, B.A. Gusterson, M.R. Crompton, Expression patterns of the novel receptor-like tyrosine kinase, DDR, in human breast tumours, Oncogene 10 (1995) 569-575.

[134] B. Neuhaus, S. Buhren, B. Bock, F. Alves, W.F. Vogel, F. Kiefer, Migration inhibition of mammary epithelial cells by Syk is blocked in the presence of DDR1 receptors, Cell. Mol. Life Sci. 68 (2011) 3757-3770.

[135] G. Turashvili, J. Bouchal, K. Baumforth, W. Wei, M. Dziechciarkova, J. Ehrmann, J. Klein, E. Fridman, J. Skarda, J. Srovnal, M. Hajduch, P. Murray, Z. Kolar, Novel markers for differentiation of lobular and ductal invasive breast carcinomas by laser microdissection and microarray analysis, BMC Cancer 7 (2007) 55.

[136] T. Ren, J. Zhang, X. Liu, L. Yao, Increased expression of discoidin domain receptor 2 (DDR2): a novel independent prognostic marker of worse outcome in breast cancer patients, Med. Oncol. 30 (2013) 397.

[137] K.A. Toy, R.R. Valiathan, F. Nunez, K.M. Kidwell, M.E. Gonzalez, R. Fridman, C.G. Kleer, Tyrosine kinase discoidin domain receptors DDR1 and DDR2 are coordinately deregulated in triple-negative breast cancer, Breast Cancer Res. Treat. 150 (2015) 9-18.

[138] I. Badiola, P. Villace, I. Basaldua, E. Olaso, Downregulation of discoidin domain receptor 2 in A375 human melanoma cells reduces its experimental liver metastasis ability, Oncol. Rep. 26 (2011) 971-978.

[139] S. Zhang, X. Bu, H. Zhao, J. Yu, Y. Wang, D. Li, C. Zhu, T. Zhu, T. Ren, X. Liu, L. Yao, J. Su, A host deficiency of discoidin domain receptor 2 (DDR2) inhibits both tumour angiogenesis and metastasis, J. Pathol. 232 (2014) 436-448.

[140] P. Canning, L. Tan, K. Chu, S.W. Lee, N.S. Gray, A.N. Bullock, Structural mechanisms determining inhibition of the collagen receptor DDR1 by selective and multi-targeted type II kinase inhibitors, J. Mol. Biol. 426 (2014) 2457-2470.

[141] S. Kothiwale, C.M. Borza, E.W. Lowe, Jr., A. Pozzi, J. Meiler, Discoidin domain receptor 1 (DDR1) kinase as target for structure-based drug discovery, Drug Discov. Today 20 (2015) 255-261.

[142] Y. Li, X. Lu, X. Ren, K. Ding, Small molecule discoidin domain receptor kinase inhibitors and potential medical applications, J. Med. Chem. 58 (2015) 3287-3301. 
[143] E. Day, B. Waters, K. Spiegel, T. Alnadaf, P.W. Manley, E. Buchdunger, C. Walker, G. Jarai, Inhibition of collagen-induced discoidin domain receptor 1 and 2 activation by imatinib, nilotinib and dasatinib, Eur. J. Pharmacol. 599 (2008) 44-53.

[144] U. Rix, O. Hantschel, G. Durnberger, L.L. Remsing Rix, M. Planyavsky, N.V. Fernbach, I. Kaupe, K.L. Bennett, P. Valent, J. Colinge, T. Kocher, G. Superti-Furga, Chemical proteomic profiles of the BCR-ABL inhibitors imatinib, nilotinib, and dasatinib reveal novel kinase and nonkinase targets, Blood 110 (2007) 4055-4063.

[145] M. Gao, L. Duan, J. Luo, L. Zhang, X. Lu, Y. Zhang, Z. Zhang, Z. Tu, Y. Xu, X. Ren, K. Ding, Discovery and optimization of 3-(2-(Pyrazolo[(1,5-a]pyrimidin-6-yl)ethynyl)benzamides as novel selective and orally bioavailable discoidin domain receptor 1 (DDR1) inhibitors, J. Med. Chem. 56 (2013) 3281-3295.

[146] H.G. Kim, L. Tan, E.L. Weisberg, F. Liu, P. Canning, H.G. Choi, S.A. Ezell, H. Wu, Z. Zhao, J. Wang, A. Mandinova, J.D. Griffin, A.N. Bullock, Q. Liu, S.W. Lee, N.S. Gray, Discovery of a Potent and Selective DDR1 Receptor Tyrosine Kinase Inhibitor, ACS Chem. Biol. 8 (2013) 2145-2150.

[147] A. Richters, H.D. Nguyen, T. Phan, J.R. Simard, C. Grutter, J. Engel, D. Rauh, Identification of type II and III DDR2 inhibitors, J. Med. Chem. 57 (2014) 4252-4262.

[148] J.S. Duncan, M.C. Whittle, K. Nakamura, A.N. Abell, A.A. Midland, J.S. Zawistowski, N.L. Johnson, D.A. Granger, N.V. Jordan, D.B. Darr, J. Usary, P.F. Kuan, D.M. Smalley, B. Major, X. He, K.A. Hoadley, B. Zhou, N.E. Sharpless, C.M. Perou, W.Y. Kim, S.M. Gomez, X. Chen, J. Jin, S.V. Frye, H.S. Earp, L.M. Graves, G.L. Johnson, Dynamic reprogramming of the kinome in response to targeted MEK inhibition in triple-negative breast cancer, Cell 149 (2012) 307321.

[149] T.J. Stuhlmiller, S.M. Miller, J.S. Zawistowski, K. Nakamura, A.S. Beltran, J.S. Duncan, S.P. Angus, K.A. Collins, D.A. Granger, R.A. Reuther, L.M. Graves, S.M. Gomez, P.F. Kuan, J.S. Parker, X. Chen, N. Sciaky, L.A. Carey, H.S. Earp, J. Jin, G.L. Johnson, Inhibition of LapatinibInduced Kinome Reprogramming in ERBB2-Positive Breast Cancer by Targeting BET Family Bromodomains, Cell Rep. 11 (2015) 390-404.

[150] D. Xu, J.D. Esko, Demystifying heparan sulfate-protein interactions, Annu. Rev. Biochem. 83 (2014) 129-157.

[151] G. Bart, N.O. Vico, A. Hassinen, F.M. Pujol, a.J. Deen, A. Ruusala, R.H. Tammi, A. Squire, P. Heldin, S. Kellokumpu, M.I. Tammi, Fluorescence resonance energy transfer (FRET) and proximity ligation assays reveal functionally relevant homo- and heterodimeric complexes among hyaluronan synthases HAS1, HAS2, and HAS3, J. Biol. Chem. 290 (2015) 1147911490. 
[152] C.M. Milner, W. Tongsoongnoen, M.S. Rugg, A.J. Day, The molecular basis of inter-alphainhibitor heavy chain transfer on to hyaluronan, Biochem. Soc. Trans. 35 (2007) 672-676.

[153] D. Nikitovic, M. Tzardi, A. Berdiaki, A. Tsatsakis, G.N. Tzanakakis, Cancer microenvironment and inflammation: role of hyaluronan, Front. Immunol. 6 (2015) 169.

[154] J. Kreuger, L. Kjellén, Heparan Sulfate biosynthesis: regulation and variability, J. Histochem. Cytochem. 60 (2012) 898-907.

[155] A. Malmström, B. Bartolini, M.A. Thelin, B. Pacheco, M. Maccarana, Iduronic acid in chondroitin/dermatan sulfate: biosynthesis and biological function, J. Histochem. Cytochem. 60 (2012) 916-925.

[156] S. Mizumoto, S. Yamada, K Sugahara, Molecular interactions between chondroitindermatan sulfate and growth factors/receptors/matrix proteins.

[157] J. Filmus, M. Capurro, J. Rast, Glypicans, Genome Biol. 9 (2008) 224.

[158] J. Filmus, M. Capurro, The glypican family, in: N.K. Karamanos (Ed.), Extracellular Matrix: Pathobiology and Signaling, De Gruyter, Berlin/Boston, 2012, pp 209-220.

[159] J. Gallagher, Fell-Muir Lecture: Heparan sulphate and the art of cell regulation: a polymer chain conducts the protein orchestra, Int. J. Exp. Pathol. 96 (2015) 203-231.

[160] X. Xian, S. Gopal, J.R. Couchman, Syndecans as receptors and organizers of the extracellular matrix, Cell Tissue Res. 229 (2010) 31-46.

[161] C.M. Lowy, T. Oskarsson, Tenascin C in metastasis: A view from the invasive front, Cell. Adh. Migr. 9 (2015) 112-124.

[162] I. Gurbuz, R. Chiquet-Ehrismann, CCN4/WISP1 (WNT1 inducible signaling pathway protein 1): focus on its role in cancer, Int. J. Biochem. Cell. Biol. 62 (2015) 142-146.

[163] D.V. Bax, Y. Mahalingam, S. Cain, K. Mellody, L. Freeman, K. Younger, C.A. shuttleworth, M.J. Humphries, J.R.Couchman, C.M. Kielty, Cell adhesion to fibrillin-1: identification of an Arg-Gly-Asp-dependent synergy region and a heparin-binding site that regulates focal adhesion formation, J. Cell Sci. 120(Pt 8) (2007) 1383-1392.

[164] M.R. Morgan, M.J. Humphries, M.D. Bass, Synergistic control of cell adhesion by integrins and syndecans, Nat. Rev. Mol. Cell. Biol. 8 (2007) 957-969.

[165] D.J. Leahy, I. Aukhil, H.P. Erickson, 2.0 A crystal structure of a four-domain segment of human fibronectin encompassing the RGD loop andsynergy region, Cell 84 (1996) 155-164.

[166] A. Sharma, J.A. Askari, M.J. Humphries, E.Y. Jones, D.I. Stuart, Crystal structure of a heparinand integrin-binding segment of human fibronection, EMBO. J. 18 (1999) 1468-1497.

[167] J.R. Couchman, Transmembrane signaling proteoglycans, Annu. Rev. Cell. Dev. Biol. 26 (2010) 89-114. 
[168] J.R. Couchman, S. Gopal, H.C. Lim, S. Nørgaard, H.A. Multhaupt, Syndecans: from peripheral coreceptors to mainstream regulators of cell behavior, Int. J. Exp. Pathol. 96 (2015) 1-10.

[169] S. Choi, J.Y. Kim, J.H. Park, S.T.Lee, I.O. Han, E.S. Oh, The matrix metalloproteinase-7 regulates the extracelluar shedding of syndecan-2 from colon cancer cells, Biochem. Biophys. Res. Commun. 417 (2012) 1260-1264.

[170] G. Gao, A. Plaas, V.P. Thompson, S. Jin, F. Zuo, J.D. Sandy, ADAMTS4 (aggrecanase-1) activation on the cell surface involves $\mathrm{C}$-terminal cleavage by glycosylphosphatidyl inositolanchored membrane type 4-matrix metalloproteinase and binding of the activated proteinase to chondroitin sulfate and heparin sulfate on syndecan-1, J. Biol. Chem. 279 (2004) 10042-10051.

[171] S. Munesue, Y. Yoshitomi, Y. Kusano, Y. Koyama, A. Nishiyama, H. Nakanishi, K. Miyazaki, T. Ishimaru, S- Miyaura, M. Okayama, K. Oguri, A novel function of syndecan-2, suppression of matrix metalloproteinase- 2 activation, which causes suppression of metastasis, J. Biol. Chem. 282 (2007) 28164-28174.

[172] C.K. Thodeti, R. Albrechtsen, M. Grauslund, M. Asmar, C. Larsson, Y. Takada, A.M. Mercurio, J.R. Couchman, U.M. Wewer, ADAM12/syndecan-4 signaling promotes beta 1 integrindependent cell spreading through protein kinase Calpha and RhoA, J. Biol. Chem. 278 (2003) 9576-9584.

[173] R.D. Sanderson, J.R. Couchman, Targeting syndecan shedding in cancer, in: N.K. Karamanos (Ed.), Extracellular Matrix: Pathobiology and Signaling, De Gruyter, Berlin/Boston, 2012, pp 802-812.

[174] S. Cattaruzza, R. Perris, Proteoglycan control of cell movement during wound healing and cancer spreading, Matrix Biol. 24 (2005) 400-417.

[175] M.A. Price, L.E. Colvin Wanshura, J. Yang, J. Carlson, B. Xiang, G. Li, S. Ferrone, A.Z. Dudek, E.A. Turley, J.B. McCarthy, CSPG4, a potential therapeutic target, facilitates malignant progression of melanoma, Pigment Cell. Melanoma Res. 24 (2011) 1148-1157.

[176] F. Granés, C. Berndt, C. Roy, P. Mangeat, M. Reina, S. Vilaró, Identification of a novel Ezrinbinding site in syndecan-2 cytoplasmic domain, FEBS Lett. 547 (2003) 212-216.

[177] T. Mori, K. Kitano, S. Terawaki, R. Maesaki, Y. Fukami, T. Hakoshima, Structural basis for CD44 recognition by ERM proteins, J. Bio.I Chem. 283 (2008) 29602-29612.

[178] E. Okina, A. Grossi, S. Gopal, H.A. Multhaupt, J.R. Couchman, Alpha-actinin interactions with syndecan-4 are integral to fibroblast-matrix adhesion and regulate cytoskeletal architecture, Int. J. Biochem. Cell Biol. 44 (2012) 2161-2174.

[179] D.A. Fletcher, R.D. Mullins, Cell mechanics and the cytoskeleton, Nature. 463 (2010) 485492. 
[180] K. Chen, K.J. Williams, Molecular mediators for raft-dependent endocytosis of syndecan-1, a highly conserved, multifunctional receptor, J. Biol. Chem. 288 (2013) 13988-13999.

[181] J.C. Gonzales, P.L. Gordts, E.M. Foley, J.D. Esko, Apolipoproteins E and AV mediate lipoprotein clearance by hepatic proteoglycans, J. Clin. Invest. 123 (2013) 2742-2751.

[182] H. Boukerche, Z.Z. Su, C. Prévot, D. Sarkar, P.B. Fisher, mda-9/Syntenin promotes metastasis in human melanoma cells by activating c-Src, Proc. Natl. Acad. Sci U S A. 105 (2008) 15914-15919.

[183] A.M. Wawrzyniak, E. Vermeiren, P. Zimmermann, Y. Ivarsson, Extensions of PDS-95/disc large/ZO-1 (PDZ) domains influence lipid binding and membrane targeting of syntenin-1, FEBS Lett. 586 (2012) 1445-1451.

[184] M.F. Baietti, Z. Zhang, E. Mortier, A. Melchior, G. Degeest, A. Geeraerts, Y Ivarsson, F. Depoortere, C. Coomans, E. Vermeiren, P. Zimmermann, G. David, Syndecan-syntenin-ALIX regulates the biogenesis of exosomes, Nat. Cell Biol. 14 (2012) 677-685.

[185] S.A. Melo, L.B. Luecke, C. Kahlert, A.F.Fernandez, S.T. Gammon, J. Kaye, V.S. LeBleu, E.A. Mittendorf, J. Weitz, N. Rahbari, C. Reissfelder, C. Pilarsky, M.F. Fraga, D. Piwnica-Worms, R. Kalluri, Glypican-1 identifies cancer exosomes and detects early pancreatic cancer, Nature. 523 (2015) 177-182.

[186] V. Orian-Rousseau, CD44 Acts as a signaling platform controlling tumor progression and Metastasis, Front. Immunol. 6 (2015) 154.

[187] A. Aspberg, The different roles of aggrecan interaction domains, J. Histochem. Cytochem. 60 (2012) 987-996.

[188] U. Günthert, M. Hofmann, W. Rudy, S. Reber, M. Zöller, I. Haussmann, S. Matzku, A. Wenzel, H. Ponta, P. Herrlich, A new variant of glycoprotein CD44 confers metastatic potential to rat carcinoma cells, Cell 65 (1991) 13-24.

[189] V. Orian-Rousseau, CD44, a therapeutic target for metastasising tumours, Eur. J. Cancer. 46 (2010) 1271-1277.

[190] L.Y. Bourguignon, D. Bikle, Selective Hyaluronan-CD44 signaling promotes miRNA-21 expression and interacts with vitamin $D$ function during cutaneous squamous cell carcinomas progression following UV irradiation, Front. Immunol. 6 (2015) 224.

[191] S. Misra, V.C. Hascall, R.R. Markwald, S. Ghatak, Interactions between Hyaluronan and its receptors (CD44, RHAMM) regulate the activities of inflammation and cancer, Front. Immunol. 6 (2015) 201.

[192] B. Greenfield, W.C. Wang, H. Marquardt, M. Piepkorn, E.A. Wolff, A. Aruffo, K.L. Bennett, Characterization of the heparan sulfate and chondroitin sulfate assembly sites in CD44, J. Biol. Chem. 274 (1999) 2511-2517. 
[193] J.A. Ajani, S. Song, H.S. Hochster, I.B. Steinberg, Cancer stem cells: the promise and the potential, Semin. Oncol. 42 (2015) Suppl 1: ppS3-17.

[194] D. Vigetti, E. Karousou, M. Viola, S. Deleonibus, G. De Luca, A. Passi, Hyaluronan: biosynthesis and signaling, Biochim. Biophys. Acta 1840 (2014) 2452-2459.

[195] J.R. Couchman, S. Vogt, S.T. Lim, Y. Lim, E.S. Oh, G.D. Prestwich, A. Theibert, W. Lee, A. Woods, Regulation of inositol phospholipid binding and signaling through syndecan-4, J. Biol Chem. 277 (2002) 49296-49303.

[196] E.S. Oh, A. Woods, S.T. Lim, A.W. Theibert, J.R. Couchman, Syndecan-4 proteoglycan cytoplasmic domain and phosphatidylinositol 4,5-bisphosphate coordinately regulate protein kinase C activity, J. Biol. Chem. 273 (1998) 10624-10629.

[197] A. Dovas, J.R. Couchman, RhoGDI: multiple functions in the regulation of Rho family GTPase activities, Biochem. J. 390 (2005) 1-9.

[198] A. Dovas, Y. Choi, A. Yoneda, H.A. Multhaupt, S.H. Kwon, D. Kang, E.S. Oh, J.R. Couchman, Serine 34 phosphorylation of rho guanine dissociation inhibitor (RhoGDlalpha) links signaling from conventional protein kinase $\mathrm{C}$ to RhoGTPase in cell adhesion, J. Biol. Chem. 285 (2010) 23296-23308.

[199] A. Yoneda, H.A. Multhaupt, J.R. Couchman, The Rho kinases I and II regulate different aspects of myosin Il activity, J. Cell. Biol. 170 (2005) 443-453.

[200] M.D. Bass, M.R. Morgan, K.A. Roach, J. Settleman, A.B. Goryachev, M.J. Humphries, p190RhoGAP is the convergence point of adhesion signals from alpha 5 beta 1 integrin and syndecan-4, J. Cell. Biol. 181 (2008) 1013-1026.

[201] S. Gopal, P. Søgaard, H.A.B. Multhaupt, C. Pataki, E. Okina, X. Xian, M.E. Pedersen, T. Stevens, O. Griesbeck, P.W. Park, R. Pocock, J.R. Couchman, Transmembrane proteoglycans control stretch-activated channels to set cytosolic calcium levels, J. Cell. Biol. 210 (2015) 1199-1211.

[202] M.N. Trebak, N. Hempel, B.J. Wedel, J.T. Smyth, G.S. Bird, J.W.Jr. Putney, Negative regulation of the TRPC3 channels by protein kinase C-mediated phosphorylation of serine 712, Mol. Pharmacol. 67 (2005) 558-563.

[203] M. Goel, W. Sinkins, A. Keightley, M. Kinter, W.P. Schilling, Proteomic analysis of TRPC5and TRPC6-binding partners reveals interaction with the plasmalemmal $\mathrm{Na}+/ \mathrm{K}+-\mathrm{ATPase}$, Pflugers Arch. 451 (2005) 87-98.

[204] A. Yoneda, M.E. Lendorf, J.R. Couchman, H.A. Multhaupt, Breast and ovarian cancers: a survey and possible roles for the cell surface heparan sulfate proteoglycans, J. Histochem. Cytochem. 60 (2012) 9-21. 
[205] V.C. Ramani, A. Purushothaman, M.D. Stewart, C.A. Thompson, I. Vlodavsky, J.L. Au, R.D. Sanderson, The heparanase/syndecan-1 axis in cancer: mechanisms and therapies, FEBS J. 280 (2013) 2294-2306.

[206] M.E. Lendorf, T. Manon-Jensen, P. Kronqvist, H.A. Multhaupt, J.R. Couchman, Syndecan-1 and syndecan-4 are independent indicators in breast carcinoma, J. Histochem. Cytochem. 59 (2011) 615-629.

[207] C.M. Alexander, F. Reichsman, M.T. Hinkes, J. Lincecum, K.A. Becker, S. Cumberledge, M. Bernfield, Syndecan-1 is required for Wnt-1-induced mammary tumorigenesis in mice, Nat. Genet. 25 (2000) 329-332.

[208] A. Farnedi, S. Rossi, N. Bertani, M. Gulli, E.M. Silini, M.T. Mucignat, T. Poli, E. Sesenna, D. Lanfranco, L. Montebugnoli, E. Leonardi, C. Marchetti, R. Cocchi, A. Ambrosini-Spaltro, M.P. Foschini, R. Perris, Proteoglycan-based diversification of disease outcome in head and neck cancer patients identifies NG2/CSPG4 and syndecan-2 as unique relapse and overall survival predicting factors, BMC Cancer. 15 (2015) 352.

[209] D.M. Beauvais, B.J. Ell, A.R. McWhorter, A.C. Rapraeger, Syndecan-1 regulates alphavbeta3 and alphavbeta5 integrin activation during angiogenesis and is blocked by synstatin, a novel peptide inhibitor, J. Exp. Med. 206 (2009) 691-705.

[210] A.C. Rapraeger, Synstatin: a selective inhibitor of the syndecan-1-coupled IGF1R- $\alpha$ V33 integrin complex in tumorigenesis and angiogenesis, FEBS J. 280 (2013) 2207-2215.

[211] J.R. Whiteford, V. Behrends, H. Kirby, M. Kusche-Gullberg, T. Muramatsu, J.R. Couchman, Syndecans promote integrin-mediated adhesion of mesenchymal cells in two distinct pathways, Exp. Cell. Res. 313 (2007) 3902-3913. 


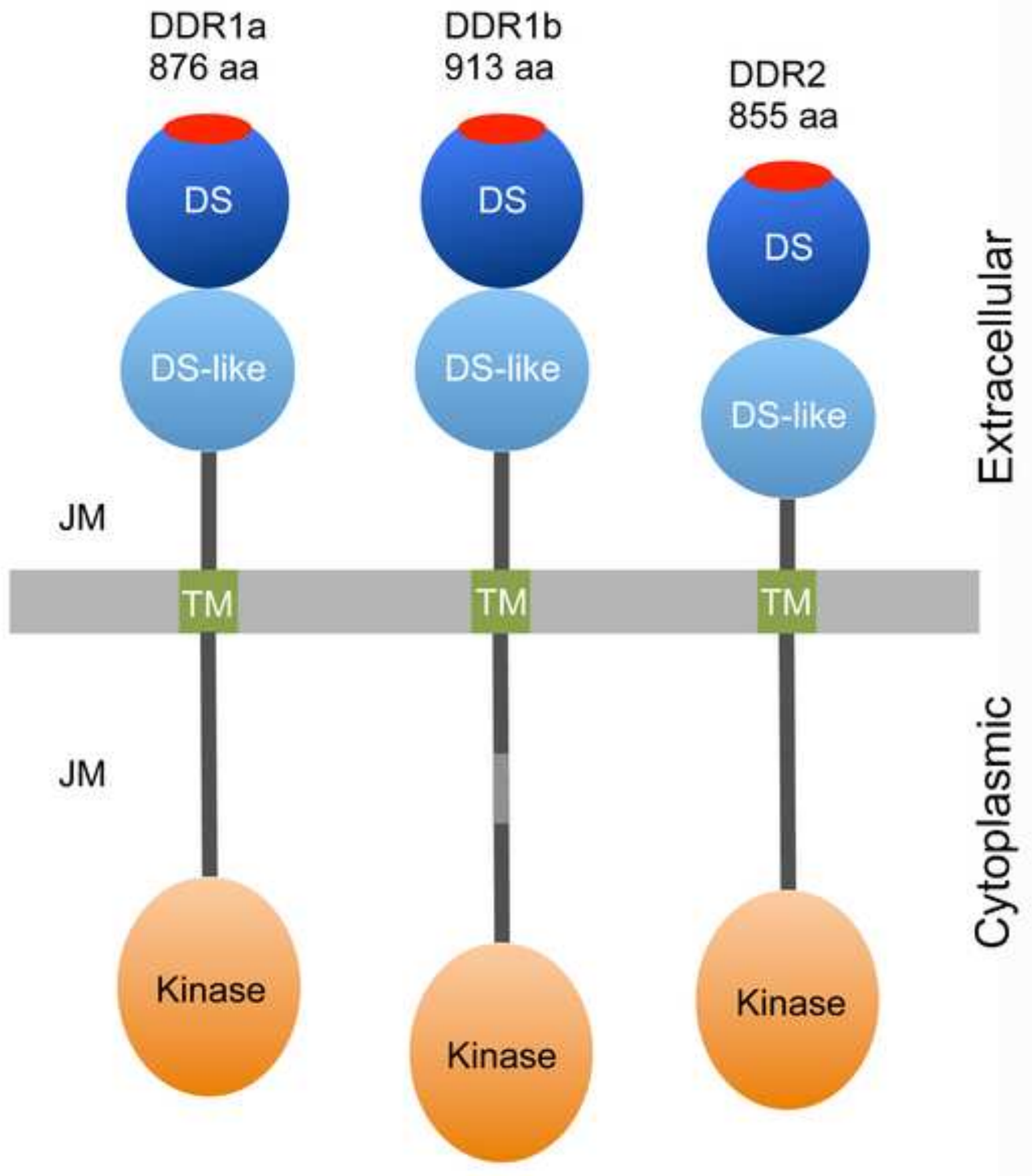


Table 1. Integrin expression on different populations of differentiated fibroblasts.

\begin{tabular}{|c|c|c|c|c|}
\hline Integrin & Ligands & Myofibroblasts & CAFs & References \\
\hline$\alpha 1 \beta 1$ & collagens & + , dermal fibroblasts (in vitro) &,++ colon & {$[24,35]$} \\
\hline$\alpha 2 \beta 1$ & collagens & + , dermal fibroblasts (in vitro) & + , colon & {$[25,35]$} \\
\hline$\alpha 11 \beta 1$ & collagens & $\begin{array}{l}+++ \text {, corneal fibroblasts, dermal } \\
\text { fibroblasts (in vitro) }\end{array}$ &,++ NSCLC & {$[26,43,47]$} \\
\hline$\alpha 3 \beta 1$ & laminins & & ++ , head- and neck, vulva & [75] \\
\hline$\alpha 5 \beta 1$ & fibronectin & & ++ , head- and neck, vulva, colon & {$[35,75]$} \\
\hline$\alpha 4 \beta 7$ & $\begin{array}{l}\text { fibronectin EDA, } \\
\text { VCAM-1, and more }\end{array}$ & + , lung & $?$ & [27] \\
\hline$\alpha 8 \beta 1$ & $\begin{array}{l}\text { fibronectin, vitronectin, } \\
\text { and more }\end{array}$ & ++ , heart, lung, liver & $?$ & {$[28,29]$} \\
\hline$\alpha 9 \beta 1$ & $\begin{array}{l}\text { fibronectin EDA, tenascin- } \\
\text { C, emilin-1, } \\
\text { and more }\end{array}$ & + , skin & $?$ & {$[30,31]$} \\
\hline$\alpha v \beta 1$ & $\begin{array}{l}\text { vitronectin, fibronectin } \\
\text { LAP }\end{array}$ & +++ , liver, lung & $?$ & [22] \\
\hline$\alpha v \beta 3$ & $\begin{array}{l}\text { vitronectin, fibronectin, } \\
\text { LAP }\end{array}$ & + , dermal fibroblasts (in vitro) & $?$ & [26] \\
\hline$\alpha v \beta 5$ & $\begin{array}{l}\text { vitronectin, fibronectin, } \\
\text { LAP }\end{array}$ &,++ dermal fibroblasts (in vitro) &,++ NSCLC, colon & [32] \\
\hline$\alpha v \beta 8$ & $\begin{array}{l}\text { vitronectin, fibronectin, } \\
\text { LAP }\end{array}$ & ++ , dermal fibroblasts (in vitro) & $?$ & [33] \\
\hline
\end{tabular}

LAP: latency associated peptide, CAF: Cancer-associated fibroblasts, NSCLC: non-small cell lung cancer,,,$++++++:$ approximate expression level, ? : not established 